\title{
FINANCIAL AND OPERATIONAL BUNDLING STRATEGIES FOR SUSTAINABLE MICRO-GRID BUSINESS MODELS
}

Peter Weston, Wakar Kalhoro | Energy 4 Impact

Eric Lockhart, Tim Reber and Samuel Booth | National Renewable Energy Laboratory 


\section{NOTICE}

This work was authored by the National Renewable Energy Laboratory, operated by Alliance for Sustainable Energy, LLC, for the U.S. Department of Energy (DOE) under Contract No. DE-AC36-08GO28308. Funding provided by the United States Agency for International Development, Power Africa. The views expressed herein do not necessarily represent the views of the DOE or the U.S. Government. The U.S. Government retains and the publisher, by accepting the article for publication, acknowledges that the U.S. Government retains a nonexclusive, paid-up, irrevocable, worldwide license to publish or reproduce the published form of this work, or allow others to do so, for U.S. Government purposes.

The tables and figures in this report are limited to use in this report only and are not to be further disseminated or used without the permission of the sources cited.

Cover photo of Jumeme Mini-Grid in Tanzania, utilized with permission of Jumeme and Energy 4 Impact.

NREL prints on paper that contains recycled content. 


\section{Acknowledgments}

The National Renewable Energy Laboratory and Energy for Impact thank the Power Africa Beyond the Grid team for supporting the development of this report. The authors would like to thank Katrina Pielli and Katie Auth in particular for their input and guidance. Thanks also go to Karlynn Cory and Robi Robichaud for their review and input. Lastly, many thanks to Britton Marchese and Lisa M. Joanis for their review and editing support. 


\section{List of Acronyms}

$\begin{array}{ll}\text { AMDA } & \text { Africa Mini-Grid Developers Association } \\ \text { DCA } & \text { Development Credit Authority } \\ \text { DFI } & \text { development finance institution } \\ \text { DFID } & \text { Department for International Development } \\ \text { E4I } & \text { Energy 4 Impact } \\ \text { ECA } & \text { export credit agency } \\ \text { EEP } & \text { Energy and Environmental Partnership } \\ \text { EnDev } & \text { Energising Development } \\ \text { ESMAP } & \text { Energy Sector Management Assistance Program } \\ \text { FMO } & \text { Nederlandse Financierings-Maatschappij voor Ontwikkelingslanden } \\ & \text { (Netherlands) } \\ \text { GIZ } & \text { Deutsche Gesellschaft für Internationale Zusammenarbeit (Germany) } \\ \text { GVE } & \text { Green Village Electricity } \\ \text { IEC } & \text { International Electrotechnical Commission } \\ \text { IEEE } & \text { Institute of Electrical and Electronics Engineers } \\ \text { KIS } & \text { Kalangala Infrastructure Services } \\ \text { KR } & \text { Kalangala Renewables } \\ \text { LCOE } & \text { life-cycle cost of energy } \\ \text { NEP } & \text { Nigerian Electrification Program } \\ \text { NESP } & \text { Nigeria Energy Support Program } \\ \text { NGO } & \text { non-governmental organization } \\ \text { NREL } & \text { National Renewable Energy Laboratory } \\ \text { O\&M } & \text { operations and maintenance } \\ \text { OECD } & \text { Organisation for Economic Co-operation and Development } \\ \text { OEM } & \text { Original equipment manufacturer } \\ \text { OPIC } & \text { Onited States Agency for International Development } \\ \text { PAYG } & \text { Overseas Private Investment Corporation (United States) } \\ \text { PPA } & \text { pay as you go } \\ \text { PPP } & \text { power purchase agreement } \\ \text { PUE } & \text { public-private partnership } \\ \text { QAF } & \text { productive uses of energy } \\ \text { RBF } & \text { quality-assurance framework } \\ \text { REPP } & \text { results-based financing } \\ \text { SAIDI } & \text { Renewable Energy Performance Platform } \\ \text { SAIFI } & \text { system average interruption duration index } \\ \text { SEforALL } & \text { system average interruption frequency index } \\ \text { Sida } & \text { Sustainable Energy for All } \\ \text { SSA } & \text { Swedish International Development Agency } \\ \text { TEDAP } & \text { TSAID }\end{array}$




\section{Executive Summary}

Micro-grids are expected to play a critical role in providing electricity access to the roughly 600 million people in Sub-Saharan Africa (SSA) who currently lack electricity. Private investment in the micro-grid sector will be necessary for the sector to scale, but it has been slow to take off in SSA because of the high level of risk relative to reward and the relatively high transaction costs as compared to larger grid-tied projects. Micro-grids are also subject to policy and regulatory risk, a lack of proven business models, and uncertainty about demand and the ability and willingness of customers to pay.

Bundling or aggregation of micro-grids is one potential solution to these challenges. At its simplest, bundling refers to combining projects or different aspects of projects into a portfolio to create efficiencies and economies of scale (e.g., reduced costs, mitigation of risks, reaching an investment size that is attractive to more financiers). There are two main types of bundling:

- Operational bundling - aggregation of similar projects (e.g., similar business model, geographical area, technology, customer type) to reduce development and operating costs and spread risk; and

- Financial bundling - aggregation of projects into a portfolio to attract more private investors through the increased size and portfolio de-risking.

The report starts off by reviewing the main elements of micro-grid business and financing models to provide necessary context. It then examines different areas of operational bundling to improve the viability of micro-grid developers and their projects, such as:

- Design and engineering;

- Installation and commissioning;

- Operations and maintenance (O\&M);

- Customer agreements;

- Standardized productive use offerings (e.g., ice making); and

- Performance monitoring and reporting.

The next section considers different forms of financial bundling such as:

- Pooled funds for micro-grid operations and growth;

- Pooled funds for electrical appliances;

- Crowdfunding; and

- Export credit finance.

Finally, the report includes two case studies which show novel approaches to micro-grid deployment and financing.

- Kalangala Infrastructure Services. Case study of a 1.6-MW micro-grid in Uganda funded by debt and equity from development finance institutions (DFIs) as part of a much larger transportand water-infrastructure project.

- Ruaha Energy. Case study of a private developer which has used grants and U.S. private placements to fund village micro-grids and grid-tied renewable projects in Tanzania.

This report is part of a series of reports being developed by the National Renewable Energy Laboratory (NREL) and Energy 4 Impact (E4I) in support of the Power Africa Beyond the Grid Program, and is a companion document to the Quality Assurance Framework for Mini-Grids (Baring-Gould et al. 2016). 
This report is a resource that developers, donors, and governments can use to understand the financial and business model challenges related to Sub-Saharan African micro-grids, and a set of emerging solutions to consider applying or supporting. For investors in particular, this report is intended to help highlight pathways to operational improvements that can lead to micro-grids becoming more attractive investments, and potential options for putting capital to work. 


\section{Contents}

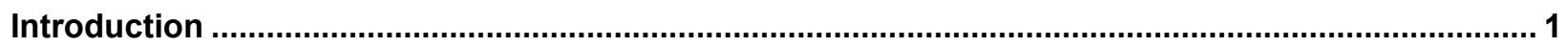

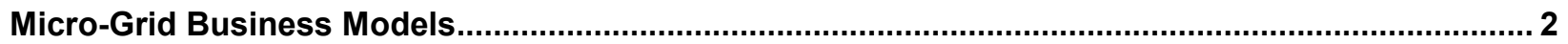

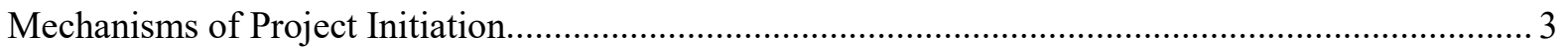

Government Tenders, Requests for Proposals, and Reverse Auctions ...................................... 4

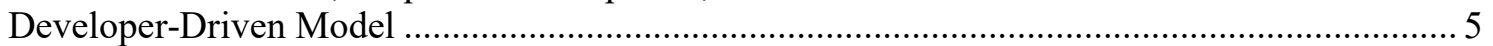

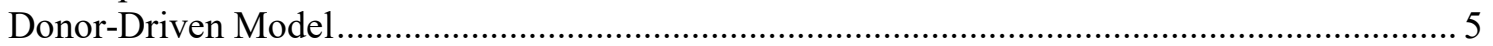

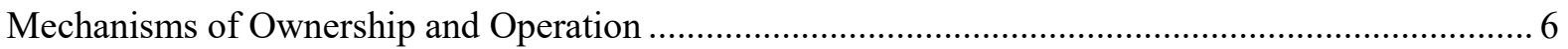

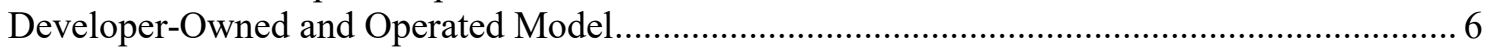

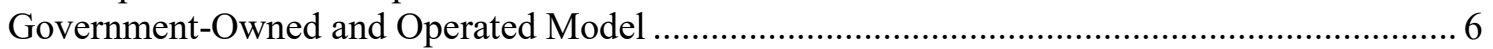

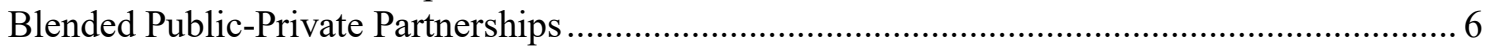

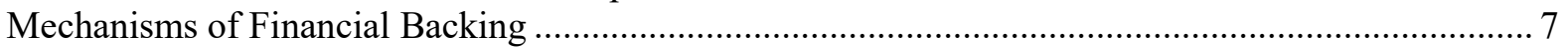

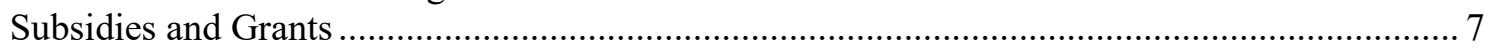

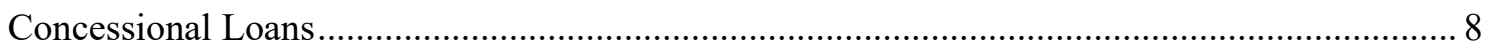

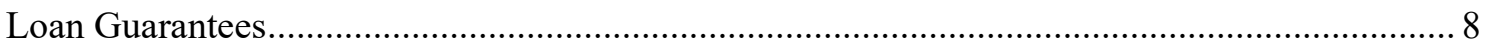

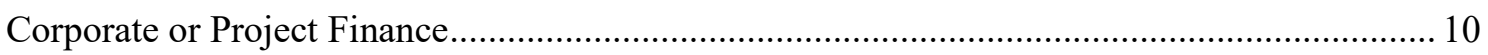

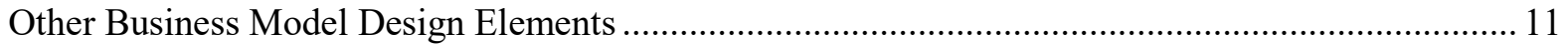

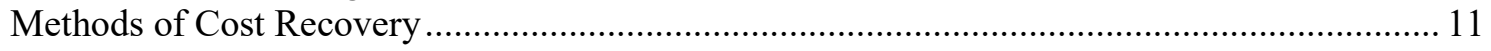

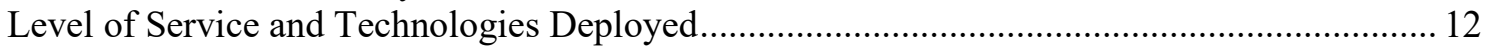

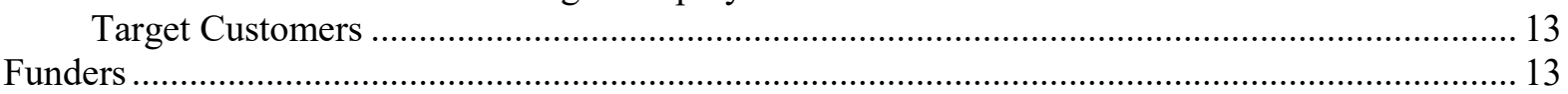

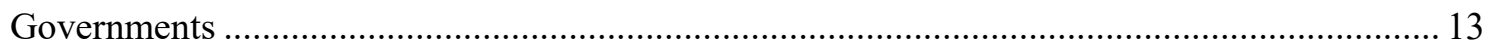

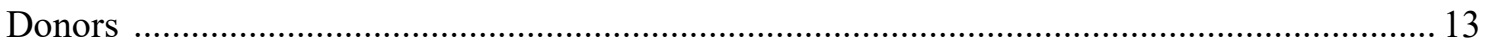

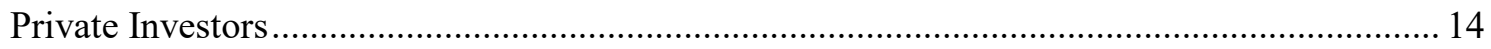

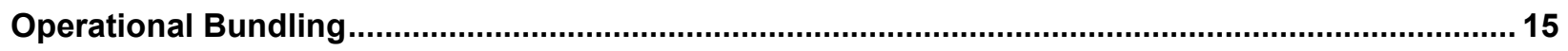

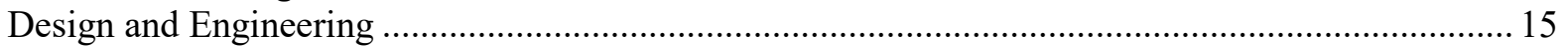

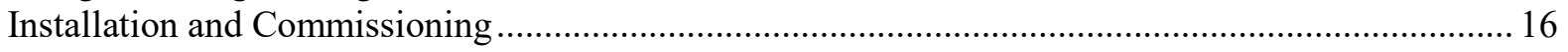

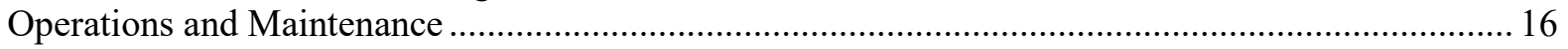

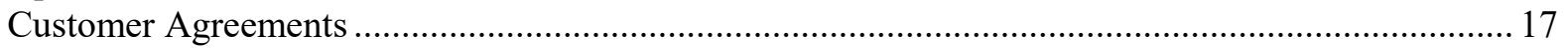

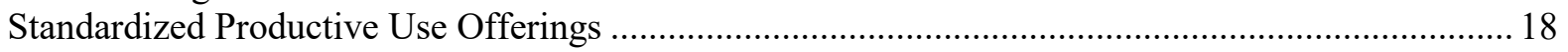

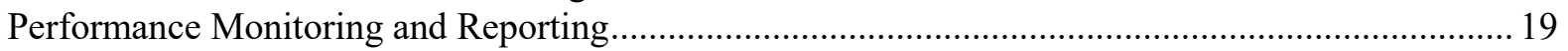

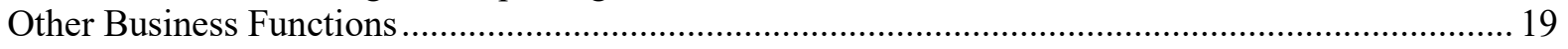

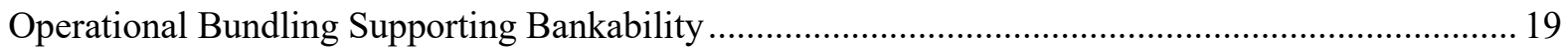

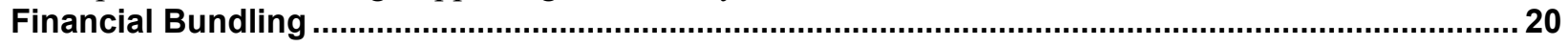

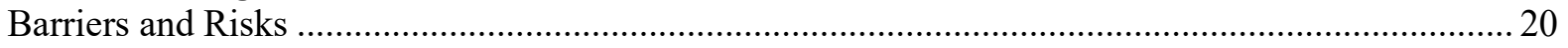

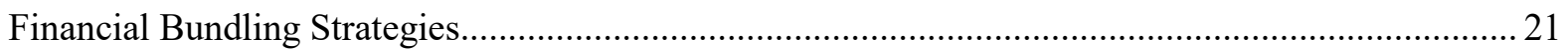

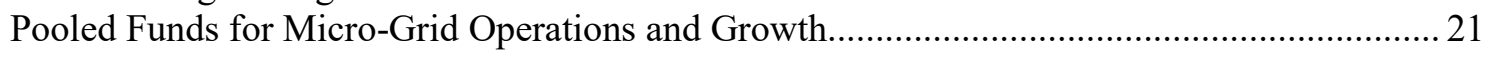

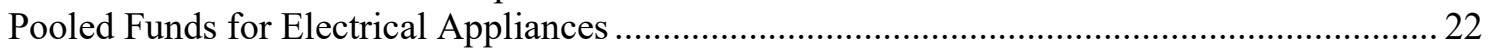

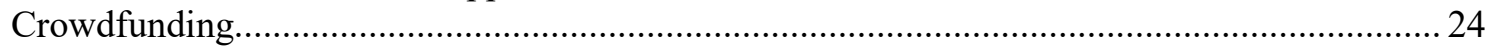

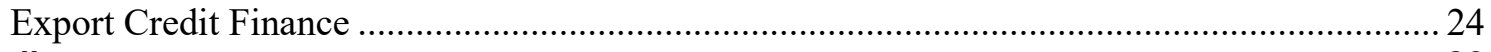

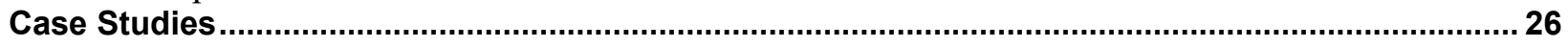

Case Study 1. Kalangala Renewables and Kalangala Infrastructure Services (Uganda) ................... 26

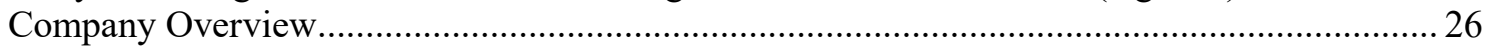

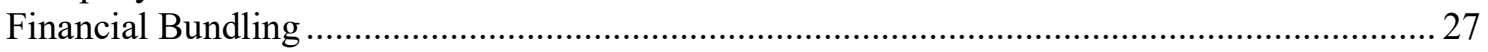

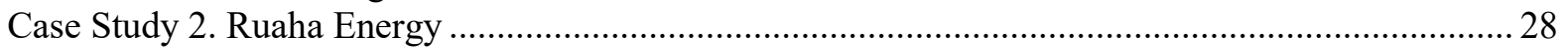

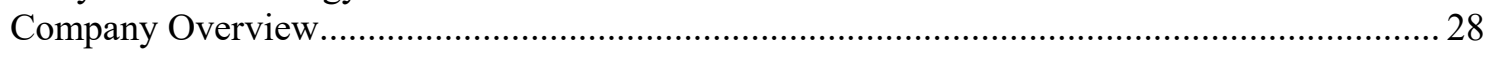

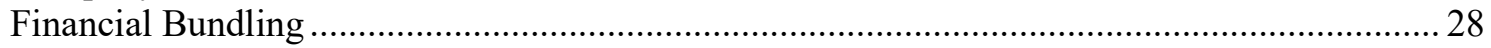

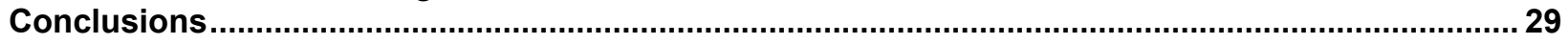

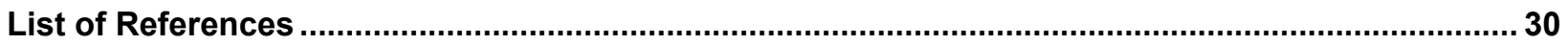

vii 


\section{List of Figures}

Figure 1. Loan guarantee.

Figure 2. Loan portfolio guarantee.

Figure 3. Selling micro-grid equipment to African governments using export finance.

Figure 5. Kalangala Renewables' solar PV array.

\section{List of Tables}

Table 1. Micro-Grid Business Models

Table 2. Differences Between Project and Corporate Finance 


\section{Introduction}

An estimated 1.1 billion people - roughly 600 million of whom live in Sub-Saharan Africa (SSA) - still lack access to modern electricity services. ${ }^{1}$ Achieving universal electricity access by 2030 is expected to require investment of roughly $\$ 45$ billion annually - more than half of which is expected to be in microgrids ${ }^{2}$ and isolated power systems. ${ }^{3}$ Investment of this scale, however, is unlikely to be met by governments and donors alone, which is why successful mobilization of private investment is so important.

The micro-grid industry in SSA is at an important inflection point. Across the continent, pilot micro-grid projects have been launched and some developers have started to achieve meaningful levels of deployment. Lessons learned from those successful developers and the donor- and government-driven programs point to the critical role of streamlining operations and using novel approaches to financing to increase the growth of the sector. As with any industry, operational and financial economies of scale are critical for long-term viability.

Different approaches to business models for micro-grids are being implemented across SSA. This diversity of approaches reflects the level of maturity of the industry, but also is an artifact of the variety of different contexts in which micro-grids operate. This report begins with the different micro-grid business and financing models currently being used, which helps to contextualize applications of bundling.

At its simplest, bundling refers to combining projects or different aspects of projects into a portfolio to improve operations and profitability or to improve ability to access competitive funding (e.g., by lowering transaction costs, mitigating risks through diversification, reaching an investment size that is attractive to more financiers). Operational bundling is covered first as a means of making micro-grids and the developers that build them into more bankable investments. This includes everything from standardizing performance monitoring to automating distribution-system design to consistent and clear customer agreements.

As the industry increasingly streamlines operations, new opportunities emerge for the second categoryfinancial bundling - as the risks and returns for micro-grid projects and developers become more predictable and the value proposition becomes clearer. Financial bundling includes everything from financial pooling mechanisms - including funds for micro-grid growth and end-user financing - to financial products for de-risking micro-grid investments.

\footnotetext{
${ }^{1}$ International Energy Agency (IEA), Energy Access Outlook 2017: From Poverty to Prosperity (Paris, France: IEA, 2017). http://www.iea.org/access2017/.

${ }^{2}$ For the purposes of this report, a micro-grid is defined as a set of electricity generators, with a capacity from 5 kilowatts up to 2 megawatts, which use significant amounts of renewable energy, feed into to a distribution network and supply electricity to a localized group of end customers. The distribution network might or might not be connected to the main electricity grid, but it is able to operate independently of the grid. The terms "mini-grid" and "micro-grid" do not have clear or consistent internationally recognized definitions and are used somewhat interchangeably by many industry stakeholders and practitioners. This report uses the single term "micro-grid" for simplicity, but does not attempt to distinguish it from the term "mini-grid," which also could apply in most instances.

${ }^{3}$ International Energy Agency (IEA), Energy for All: Financing Access for the Poor (Paris: International Energy Agency, 2011). http://www.worldenergyoutlook.org/media/weowebsite/2011/weo2011_energy_for_all.pdf.
} 


\section{Micro-Grid Business Models}

This section explores the different models for expanding micro-grid deployment in SSA and bringing in more private sector investment, providing some context for the later sections on operational and financial bundling. Currently, there is no proven business model for private-sector-driven micro-grids that has been able to scale - many are being tried, but the road to broad financial sustainability remains unclear and the industry is likely to require grants, subsidies, seed equity, and concessional loans to build up the necessary track record and create the conditions for private financing to occur.

It is useful to examine the traditional utility model and the challenges of applying it to micro-grids in SSA. The traditional utility business model has four critical stakeholder groups with different needs: (1) Customers require reliable electricity that meets their needs at a price that they can afford and are willing to pay; (2) power suppliers must provide electricity that meets the expectations of customers while assuring that costs are consistently covered over time and eventually provide satisfactory returns; (3) investors must understand risks and the pathways to mitigate them and receive a return that is commensurate with the level of risk; and (4) governments play a role in trying to balance the diverse interests of these and other peripheral stakeholder groups through policy and regulatory measures.

This utility model faces several important barriers when applied to micro-grids. Customer demand and expectations can be difficult to predict, and this can lead to unreliable cash flow for power suppliers. Additionally, suppliers face higher costs of power provision because many micro-grids are located in sparsely populated and remote rural areas. The suppliers often have limited options for cost recovery because local regulations in many SSA countries prevent or inhibit cost-reflective tariffs. ${ }^{4}$ The lack of clear regulations around licensing and compensation for arrival of the main grid is another problem. As a result, investors find it difficult to evaluate the risks and viability of micro-grid businesses and find effective ways to put capital to work. ${ }^{5}$

The Quality Assurance Framework (QAF) for isolated mini-grid power systems (Baring-Gould et al. 2016) was developed to help address many of these issues. ${ }^{6}$ The QAF defines a range of service levels that ensure safe, quality, and affordable delivery of electricity, and provides an accountability framework that can be used to determine whether an agreed-upon service level is delivered. The implementation of the principles in the QAF enables all micro-grid stakeholders - from the investor to the customer-to use common terminology and have a common understanding of their respective roles and responsibilities, thus helping to develop viable business models for the industry. The QAF is discussed in more detail in the section on operational bundling below.

There is no one-size-fits-all business model for micro-grids. However, a number of innovative approaches have been piloted in different markets in an attempt to overcome barriers and expand electricity access. Table 1 summarizes some elements of emerging micro-grid business models, including different mechanisms for project initiation, cost recovery, ownership and operation, and financial backing. These are explained in more detail in the sections below.

\footnotetext{
${ }^{4}$ For an overview of micro-grid tariffs, see "Tariff Considerations for Micro-Grids in Sub-Saharan Africa" (NREL, 2018). https://www.nrel.gov/docs/fy18osti/69044.pdf.

${ }^{5}$ For an overview of the micro-grid sector, see "Green Mini-Grids in Sub-Saharan Africa: Analysis of Barriers to Growth and the Potential Role of the African Development Bank in Supporting the Sector" (Energy 4 Impact and Inensus, 2016).

${ }^{6}$ For more information, see “Quality Assurance Framework for Mini-Grids” (Baring-Gould et al., 2016).
} 
Table 1. Micro-Grid Business Models

\begin{tabular}{|c|c|}
\hline Business Model & Options \\
\hline $\begin{array}{l}\text { Mechanism of } \\
\text { Project Initiation }\end{array}$ & $\begin{array}{l}\text { Government driven } \\
\text { - Tenders and requests for proposal } \\
\text { - Reverse auctions } \\
\text { Developer driven } \\
\text { - Developer identifies commercial sites } \\
\text { - Public-private partnerships } \\
\text { Donor driven } \\
\text { - Support for individual developers or projects } \\
\text { - Identification by donors and implementation with partners } \\
\text { - Partnership with government }\end{array}$ \\
\hline $\begin{array}{l}\text { Mechanism of } \\
\text { Ownership and } \\
\text { Operation }\end{array}$ & $\begin{array}{l}\text { Developer owned and operated: Developer owns and operates micro-grid } \\
\text { assets for profit } \\
\text { Government owned and operated: Developer transfers assets to government } \\
\text { Blended public-private partnerships }\end{array}$ \\
\hline $\begin{array}{l}\text { Mechanism of } \\
\text { Financial Backing }\end{array}$ & $\begin{array}{l}\text { Subsidies } \\
\text { - Connection based } \\
\text { - } \text { Production based } \\
\text { - } \text { Buy-downs } \\
\text { Concessional loans } \\
\text { Government or donor funded } \\
\text { Risk-mitigation instruments (e.g., loan guarantees) } \\
\text { Private investment } \\
\text { - Equity investments } \\
\text { - Debt financing }\end{array}$ \\
\hline $\begin{array}{l}\text { Other Key Design } \\
\text { Elements }\end{array}$ & $\begin{array}{l}\text { Mechanism of cost recovery } \\
\text { - Post-paid } \\
\text { - Prepaid } \\
\text { - Alternative revenue sources } \\
\text { Levels of service and technologies deployed } \\
\text { Target customers }\end{array}$ \\
\hline
\end{tabular}

\section{Mechanisms of Project Initiation}

This section examines the different ways that micro-grid projects are initiated, namely by governments, developers, and donors. For a given country, micro-grid deployment can include all three types of project initiation, but it is important to dissect each type because they have different advantages and disadvantages, and the emphasis on one versus another will have ramifications for the enabling policy and regulatory environments. They also translate into different roles for private investment. 


\section{Government Tenders, Requests for Proposals, and Reverse Auctions}

In this approach of project initiation, a government entity seeks to procure a certain number of microgrids or a certain capacity of electricity generation through a public call for projects, typically with a set of eligibility requirements for bidders and types of projects.

Tenders or requests for proposals (RFP) increasingly are being used as a means of sourcing micro-grid projects. They are particularly well-suited for a country or region which has technology- or geographicspecific electrification or renewable energy development goals. For example, a state within a country might lag behind national benchmarks in electrification. A national government therefore might put out a request for a certain number of micro-grids with a set of specifications in that state, or provide incentives or fast-track licensing or regulatory processes to facilitate targeted expansion.

One example of this is the "Pro Micro-Grids" program in Uganda, which is running a tender for microgrids in about 25 villages in the northern part of the country. The program is managed by Uganda's Rural Electrification Agency with funding and support from the Deutsche Gesellschaft für Internationale Zusammenarbeit (GIZ). ${ }^{7}$ Additional support to help develop the enabling environment for micro-grids is being provided, such as electrification planning, promoting private sector-friendly regulations, simplifying licenses and approvals, preparing pre-feasibility studies, and facilitating productive use of electricity. Other countries where micro-grid tenders are being promoted include Democratic Republic of Congo, Madagascar, Nigeria, and Sierra Leone.

Reverse auctions are a popular approach to tenders for promoting renewable projects because of the advantages they bring in terms of price discovery, flexibility, contractual commitments, and potentially reduced tariffs. A reverse auction is one in which the roles of buyer and seller are reversed. In an ordinary auction, buyers compete to obtain goods or services by offering increasingly higher prices. In a reverse auction, the sellers compete to obtain business from the buyer, and prices typically decrease as the sellers underbid each other. In the case of renewable energy projects, developers tend to compete based on the price of electricity generated or the amount of subsidy in a tariff. Examples of African countries using utility-scale renewable energy auctions include South Africa and Zambia. Auctions for micro-grids were used in Senegal and also now are being considered for micro-grids in Nigeria and the Democratic Republic of Congo.

Micro-grid tenders and auctions require a clear, transparent, and enforceable regulatory framework and strong public support. ${ }^{8}$ They should also have a predictable and relatively simple design which keeps transaction costs down and reflects the low level of maturity in the market. This can be achieved in a number of ways:

- Having clear objectives. Tenders, for example, can specify a goal for a certain number of connections and define criteria for a connection, such as minimum supply standards or geographical location.

- Holding pre-tender or pre-auction bidders' workshops. These workshops can help increase the number and quality of potential bids.

- Simplifying the pre-qualification criteria. This can make it easier for developers to bid, increasing the number and range of bidders.

- Identifying the right micro-grid sites and clusters to ensure scale. Where feasible, up-front identification of sites or clusters can drive bids towards tender or auction objectives. This option, however, does increase tender administration costs and reduces the options for developers to

\footnotetext{
${ }^{7}$ GIZ is the technical arm of the German Federal Ministry for Economic Cooperation and Development.

${ }^{8}$ UK Aid, "Auctions as a Potential Mechanism to Accelerate Green Mini-Grids in Africa" (2018).
} 
leverage their experience and identify their own sites which might be more financially viable. The costs and benefits of each approach should be weighed against the desired objectives (e.g., electrification of target areas).

- Results-based payments. Payments should be based on results that are relevant for the auction or tender, such as making payments for new connections rather than installed capacity. If pursuing this option, it is important that the results are straightforward to verify. The following section on mechanisms of financial backing provides additional information about results-based financing options.

- Allowing alternative revenue streams and cost-reflective tariffs. Where feasible, allowing alternative revenue streams can open the auction or tender to innovative cost-recovery options. Cost-reflective tariffs can improve the economics for developers and increase the likelihood that the tender will bring in sufficiently strong bids to achieve its objectives.

- Provisions for the extension of the grid. This could include providing a clear and acceptable compensation mechanism for developers in case the main grid arrives.

\section{Developer-Driven Model}

On the other end of the spectrum is the developer-driven model in which the national government and relevant regulatory bodies seek to create an enabling environment for micro-grid expansion but are agnostic regarding the location of micro-grids or the technology used. In this scenario, the siting and design of micro-grids is left to the discretion of developers. Although this approach might reduce the cost for the government (administratively or otherwise), it also leaves the level of electrification and its equitable distribution in the hands of the private sector-which is likely to pursue projects based on riskadjusted returns for invested capital.

\section{Donor-Driven Model}

The most common mechanism for project initiation to date is donor driven. There are three primary approaches to donor-driven deployment.

1. Donors fund and execute the micro-grid deployment directly.

2. Donors support particular developers or projects for implementation through private-sector or non-governmental partners.

3. Donor programs are executed by a government body, such as a rural electrification agency, and the program design and allocation of funds become joint decisions of the donors and national governments.

Although not a sustainable business model approach for the scale-up of micro-grids, donor-driven microgrid development can help test approaches or provide donors and developers with pilot-project experience and a track record necessary to attract more sustainable private capital. Implementation results, even those with significant lessons learned, can increase the confidence and reduce perceived risk for subsequent investors.

Early experience points to a few common design elements of successful project initiation approaches, including:

- Developing an investor-friendly regulatory framework, which includes cost-reflective tariffs and clear compensation mechanisms for arrival of the main grid;

- Preparing a suite of investor-friendly agreements which can become the template for the rest of the sector; and 
- Supporting access to finance and training of the commercial-banking sector.

\section{Mechanisms of Ownership and Operation}

Once a micro-grid project is commissioned, there can be a transfer of ownership and responsibilities for long-term operation and maintenance of the system. Ownership and operational roles can be structured in a variety of ways, but three structures have risen to prominence.

1. Private-developer owned and operated.

2. Government-owned and operated or publicly owned and operated.

3. Blended approach in which both governments and private firms have defined roles, usually known as a public-private partnership (PPP).

\section{Developer-Owned and Operated Model}

Under a developer-owned and operated model, a micro-grid developer maintains ownership and takes on the role of power-system operator. In some cases, the developer is accountable to investors that have provided equity and debt financing. In other cases, the investor itself legally "owns" the system and the developer simply operates it on the investor's behalf. In both cases, the concept remains the same - the micro-grid must provide returns commensurate with risk.

\section{Government-Owned and Operated Model}

At the other end of the spectrum are government-owned and operated systems. Owners of such systems may include a national government (e.g., rural electrification agency, vertically integrated national utility), a local government entity, or a community that the micro-grid serves. A national utility could develop the systems - for example by contracting with an engineering and procurement firm. Once commissioned, the micro-grid can then be operated as a public service. The government could also contract out operations, often on a rotating award basis. In the end, however, it still retains ownership and the ultimate responsibility for operations. Although increased private investment is critical, mature microgrid industries still could employ a mix of ownership and project initiation approaches across any given country, and government ownership might open up opportunities for cross-subsidization across microgrids and central grids. In this ownership model, the government entity's need to cover its costs through revenue collection must be balanced against other priorities it might have for operating the systems.

\section{Blended Public-Private Partnerships}

Between these two models is a variety of blended approaches that can be used for public-private partnerships (PPPs). The exact structure and terms of a PPP can vary significantly between countries and between projects. In essence, however, both the government and private sector have clearly defined and mutually beneficial roles from the start. For example, a government could grant service licenses and concessional funding to private developers, who in exchange agree to provide a certain level of service at an agreed-upon (often below-market) rate. In many cases, PPP projects can be executed directly between a private enterprise and a local government or community association (which plays a role in owning and operating the system for its community).

In any of the models, it is important to highlight the difference between the generation infrastructure (e.g., solar panels, diesel generators) and the distribution infrastructure (e.g., power lines). In many cases, a "micro-grid" encompasses both generation and transmission assets, and a single entity is responsible for both, although this is not always the case. 


\section{Mechanisms of Financial Backing}

This section covers common forms of financial backing for developer-owned micro-grids, and for microgrids operated through a PPP.

\section{Subsidies and Grants}

One of the most common mechanisms to deliver financing to a micro-grid project is through the provision of subsidies and grant funding. These financial instruments can take several forms, including but not limited to:

- Connection subsidies that provide a predetermined, up-front amount to the developer for each household or business connected to the micro-grid;

- Production subsidies that provide an annual subsidy to the micro-grid operator based on the quantity of energy produced or delivered (e.g., $\$ / \mathrm{kWh})$;

- Buy-downs in which the guarantor or donor "buys" a portion of a developer's debt to reduce the principal or interest amount and thus the repayment that must be made; and

- Grants or cash subsidies that are single, lump-sum grants offered based on some other measurable or project-relevant criteria.

Although this list is not exhaustive, it shows how direct grants and subsidies are often provided to developers. These mechanisms, however, do not typically cover the full cost of a micro-grid and might be available only after the system has been commissioned - which means that the private sector still must take on most of the up-front development and construction risk and provide capital for equipment, engineering, and construction services. These mechanisms also offer different incentives for system design and cost recovery.

To ensure that incentives are appropriately aligned, many of the micro-grid donor programs in SSA today include some element of results-based financing (RBF). RBF is a mechanism for linking subsidies to predetermined results, with payment made only after verification that the agreed-upon results have been delivered. In the context of micro-grids, RBF links grants or subsidies to new connections. Recipients will typically receive a payment for each new connection, subject to verification that the connections meet a pre-determined set of criteria. For example, criteria may include service level standards that correspond to the definitions laid out in national electrification plans. Verification procedures will vary but can draw on practices in place for public utilities in a given jurisdiction.

RBF can be effective for both government- and developer-driven project initiation. Whichever project initiation model is used, RBF programs tend to work better if they have clear objectives, a relatively simple design and application process, and are based on results that are easy to verify. Because the subsidies are not paid up front, recipients initially must raise their own financing so RBF programs are likely to be better suited for well-capitalized developers. In theory, the RBF itself should make it easier for developers to raise financing because the RBF grant can be used to repay any early-stage investment.

Examples of current RBF programs include:

- Energising Development (EnDev $)^{9}$ in Rwanda and Kenya, and

- Two Department for International Development (DFID) funded programs in:

- Kenya (implemented by AFD of France and now co-funded by the EU), and

\footnotetext{
${ }^{9}$ See more in EnDev's recent report evaluating the performance of its RBF programs. https://endev.info/images/3/34/EnDev_RBF_lessons_learnt_report_2017.pdf.
} 
○ Tanzania ${ }^{10}$ (implemented by the Rural Energy Agency and co-funded by Sida of Sweden).

- The African Development Bank has drawn up plans for a multi-donor pan-African RBF fund for green micro-grids, in close collaboration with the Africa Mini-Grid Developers Association (AMDA).

Some micro-grid RBF programs have received mixed reviews from developers, mainly because the funds have not been disbursed in an efficient way (e.g., too slow, less than the amounts expected, subject to changing rules).

\section{Concessional Loans}

One of the biggest challenges for scaling-up the micro-grid sector is the lack of available loans. Commercial lenders are risk-averse, lack knowledge of the sector, and are reluctant to lend to micro-grids until the business model is more proven. Local banks tend to offer relatively short-term loans, have significant collateral requirements, and charge high interest rates - these can be $20 \%$ to $30 \%$ for local currency loans, and in some instances are as much as $40 \%$. International lenders often are more concerned about foreign-exchange risk and are not interested in the small investment opportunities currently available in the micro-grid sector. Additionally, many developers are not familiar with the needs of different lender types, how to approach them, and how to effectively package the business model presentation.

Governments and donors can partly fill the funding gap by providing concessional loans which offer more-attractive terms than the private sector (e.g., longer tenor, below-market rates). These loans can be provided directly to developers through DFIs or indirectly through cheap on-lending facilities (or loan guarantees for commercial banks). There is a risk that some micro-grids might be overlooked in this process because DFIs tend to target larger projects and some lend only through governments and their agencies. Furthermore, the DFIs have relatively complex due-diligence processes and high transaction costs, which makes them less attractive for micro-grids when they are not effectively bundled.

A good example of concessional lending is the Bank of Industry in Nigeria, which offers single-digit interest rate loans to micro, small, and medium enterprises, and is currently supporting one of the country's largest micro-grid developers (Green Village Electricity or GVE) which has installed 12 microgrids totaling $500 \mathrm{~kW}$. Other DFIs that have been active in the micro-grid sector include Overseas Private Investment Corporation (OPIC) and Nederlandse Financierings-Maatschappij voor Ontwikkelingslanden (FMO) from the United States and Netherlands respectively. ${ }^{11}$

\section{Loan Guarantees}

Rather than providing the loans themselves, governments and donors can offer guarantees to private lenders that loans will be repaid in the event of default by a micro-grid owner or developer. These loan guarantees reduce the risk to lenders and potentially enable them to offer more-attractive loan terms.

At its simplest, a loan guarantee is a promise by a guarantor to an identified lender to assume the debt obligations of an identified borrower (i.e., the micro-grid developer or project owner) - see Figure 1 below. Such guarantees usually cover $50 \%$ of the outstanding principal of the loan, but can be moreeven $75 \%$ - to encourage banks to offer more-attractive terms.

\footnotetext{
${ }^{10}$ This program offers developers subsidies of between $\$ 300$ and $\$ 600$ per connection depending on the tier of electricity service.

${ }^{11}$ These institutions can have mandates that include promotion of locally-made technologies as exports to other countries.
} 
Loan guarantees can be provided to the lenders directly or through third-party organizations, such as the African Guarantee Fund or GuarantCo. Whichever approach is taken, it is important that the structure caters to micro-grid business models. The financial product can be made more attractive to the micro-grid developers by including a sufficiently long tenor and reasonable collateral requirements and interest rates. The process for approving the guarantees and triggering any payout should be reasonably quick and straightforward. ${ }^{12}$

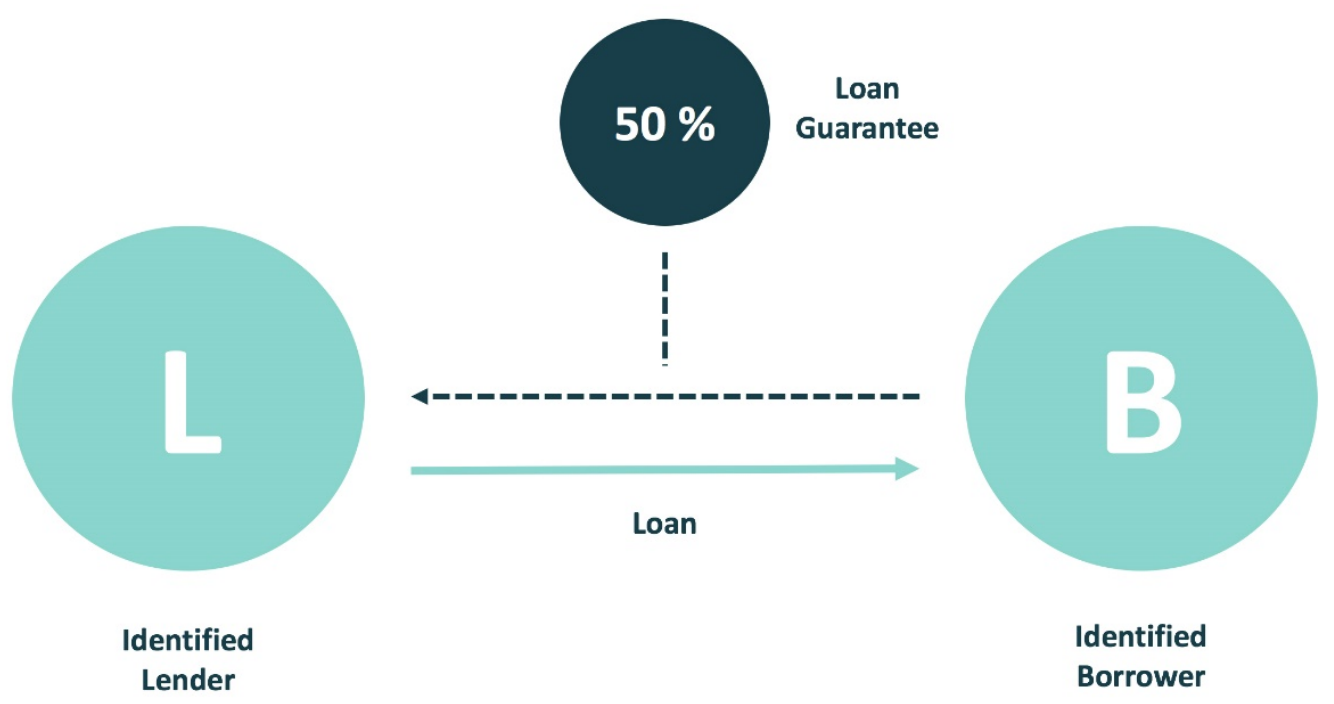

Figure 1. Loan guarantee.

There are different varieties of loan guarantees. Although standard loan guarantees cover full and timely repayment of a loan up to a predetermined amount, a risk guarantee covers all or part of a loan or investment and is paid out only if specific risks or events cause a default. Examples of such risks include non-payment or late payment by an anchor customers and lower-than-expected electricity sales. Electricity sales risk could be partly mitigated by a full or partial guarantee to cover short-term liquidity problems caused by seasonal variations in electricity demand. Such guarantees will be particularly important in the early years of the operation of a micro-grid when there is little or no demand history.

So far, there have been very few examples of individual micro-grid projects securing loans or supporting loan guarantees. This is because of the relatively small size of most micro-grid transactions and the risk aversion of lenders, which can make the cost of setting up a loan guarantee prohibitively expensive. Kalangala Infrastructure Services is a notable exception (see the Case Studies section below).

A loan portfolio guarantee is potentially a better instrument for micro-grids than an individual loan guarantee because it allows for multiple borrowers, each of which can be smaller in size. It guarantees a portfolio of loans made by a lender to a target borrower segment (e.g., energy access companies, including micro-grid developers and projects) for which the parameters have been defined (e.g., rates, terms, geography, technology, business model) but the individual borrowers are not known. The framework is shown in Figure 2. The terms of the guarantee include the portfolio limit (i.e., the total value of loans to be covered), the coverage rate (typically no more than $50 \%$ of the outstanding principal on the loans, although some could be more), the maximum tenors of the loans (typically 10 years is required for most micro-grids), the currency of the loans (most are in hard currency), and the guarantee costs.

\footnotetext{
${ }^{12}$ For the key elements of a successful loan guarantee program, see "Green Mini-Grids in Sub-Saharan Africa: Analysis of Barriers to Growth and the Potential Role of the African Development Bank in Supporting the Sector" (Energy 4 Impact and Inensus, 2016), pp. 30-31.
} 


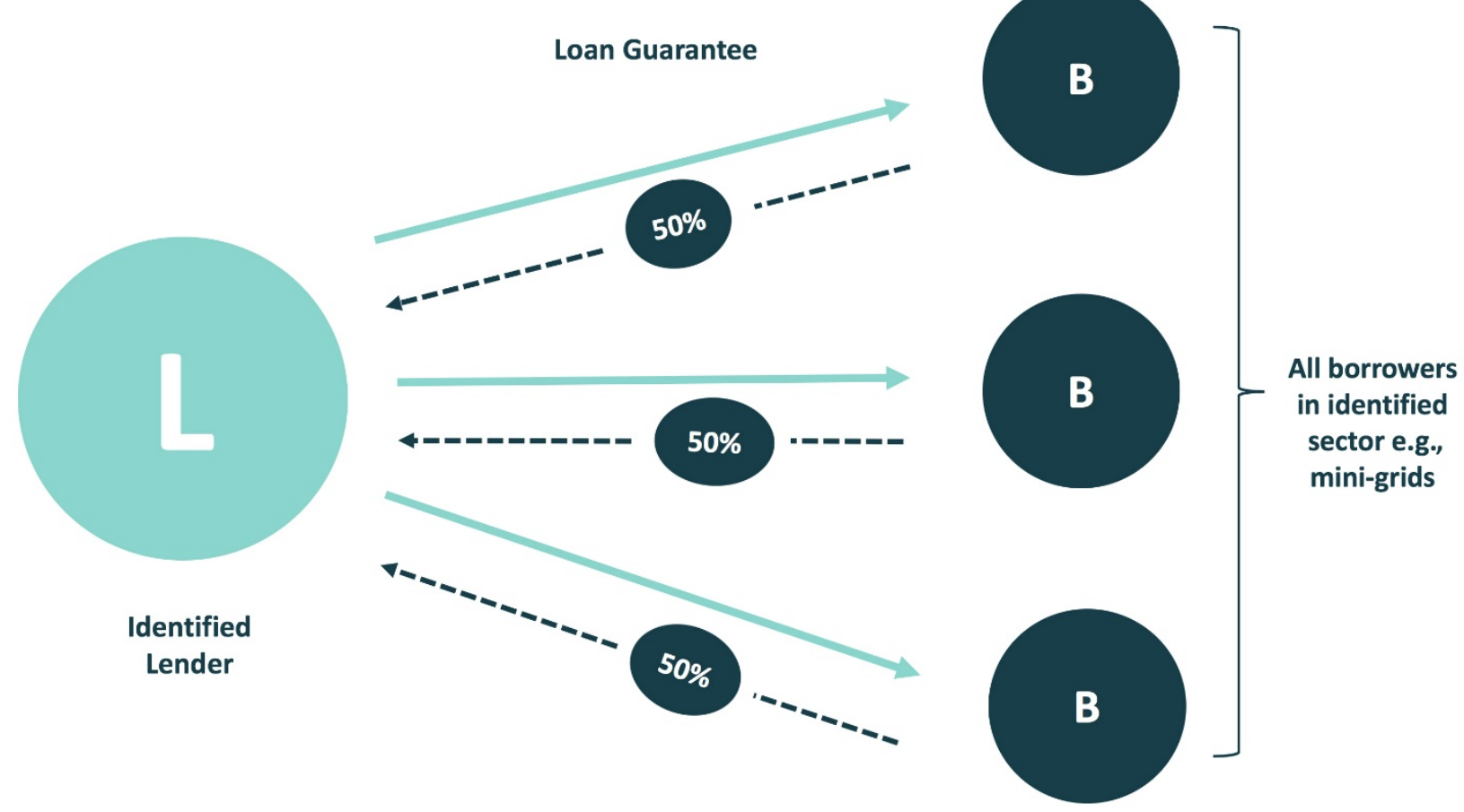

Figure 2. Loan portfolio guarantee.

Donors such as USAID have launched loan-guarantee schemes for off-grid energy. ${ }^{13}$ Some peer-to-peer lending platforms also have recently secured loan-portfolio guarantees for off-grid energy, ${ }^{14}$ but it is too early to say whether these will facilitate micro-grid loans. Donor-funded organizations, such as the African Guarantee Fund, are able to offer guarantees for relatively small portfolios (e.g., \$1 million to $\$ 5$ million) and their fees are relatively low relative to the loan amounts they are guaranteeing. The fees charged depend mainly on the risk profile of the portfolio and the track record of the platform.

\section{Corporate or Project Finance}

Micro-grids can be financed with private-sector equity or debt at either the level of the developer (i.e., corporate finance) or the level of the micro-grid (i.e., project finance). For all but the largest developers, corporate finance is likely to be more practical, quicker, and cheaper to execute than project finance. Investors can spread their risk across all the developer's projects and therefore need less-detailed due diligence on individual projects. Project finance is likely to only be an option for the larger micro-grids (approximately $1 \mathrm{MW}$ and greater) or for groups of smaller grids which have anchor customers that offer long-term contracted revenue streams (which are very difficult to find). Most micro-grids are too small an investment to justify the significant up-front structuring and due diligence costs, and they do not have sufficiently reliable, long-term cash flows for project finance. A project finance loan of less than $\$ 20$ million could be difficult to justify because of these high fixed costs. Table 2 shows the main differences between corporate and project finance.

\footnotetext{
${ }^{13}$ In 2015, USAID's Development Credit Authority (DCA) launched a \$75M loan guarantee scheme for off-grid energy. Working through a small number of lending institutions, it guaranteed long-term loans in local currency from a few thousand dollars up to $\$ 5$ million.

${ }^{14}$ See "Crowdfunding" in the Financial Bundling section of this report.
} 
Table 2. Differences Between Project and Corporate Finance

\begin{tabular}{l|l}
\hline Project Finance & Corporate Finance \\
\hline $\begin{array}{l}\text { Investment based on income projections for } \\
\text { individual micro-grid or group of micro-grids. }\end{array}$ & $\begin{array}{l}\text { Investment based on historical track record of } \\
\text { developer and income projections of developer's } \\
\text { micro-grid portfolio. }\end{array}$ \\
\hline $\begin{array}{l}\text { Most suitable for larger micro-grids with } \\
\text { anchor customers that offer long-term } \\
\text { contracted revenue stream. }\end{array}$ & Suitable for all types of micro-grids. \\
\hline $\begin{array}{l}\text { Funds only to be used for project(s) specified } \\
\text { in financing agreement. }\end{array}$ & $\begin{array}{l}\text { More freedom for developers to use funds across } \\
\text { different projects. }\end{array}$ \\
\hline $\begin{array}{l}\text { Project risks shared among investors } \\
\text { supporting specific project. }\end{array}$ & $\begin{array}{l}\text { Balance-sheet impact on developer (and } \\
\text { corporate investors). }\end{array}$ \\
\hline $\begin{array}{l}\text { Financing takes longer to execute and } \\
\text { results in greater up-front costs. }\end{array}$ & $\begin{array}{l}\text { Shorter time to execute financing and lesser up- } \\
\text { front costs. }\end{array}$ \\
\hline $\begin{array}{l}\text { Complex contract structure / more due } \\
\text { diligence. }\end{array}$ & Simpler / less due diligence. \\
\hline $\begin{array}{l}\text { Longer-term financing based on project } \\
\text { life cycle, risks, and expected cash flows. }\end{array}$ & $\begin{array}{l}\text { Shorter-term financing based on developer } \\
\text { fundamentals, risks, and expected cash flows. }\end{array}$ \\
\hline
\end{tabular}

\section{Other Business Model Design Elements}

There are a few additional attributes of business model design that cut across the elements of project initiation, ownership, and financial backing. These include methods of cost recovery, the level of service provided, and target customers.

\section{Methods of Cost Recovery}

A key element of business model design is the mode of cost recovery. Effective cost recovery is a cornerstone of attracting financing and building a sustainable and scalable business.

\section{Post-Paid}

A traditional utility model for grid-connected customers is post-paid, meaning that customers are billed at the end of each month for electricity used during that billing period. This payment method is included here for completeness but requires reliable payments, and risks that are spread across a large number of households, so it is generally not appropriate for micro-grids which have a smaller number of connected customers and lack effective recourse for services rendered but not compensated.

\section{Prepaid}

A more popular approach for micro-grids is prepaid credit, often on a month-ahead basis, either for kilowatt-hours or time for a set of devices. One approach is for a system operator to offer electricity at a given price per unit of energy (in \$ per $\mathrm{kWh}$ ). The other approach is an agreement in which the operator powers a preselected set of devices during a certain period (e.g., two light bulbs and a radio from 17:00 to 
20:00 each day). In this second approach, energy services typically are sold in prepaid daily, weekly, or monthly packages.

\section{Alternative Revenue Sources}

Another mechanism for cost recovery is tapping alternative revenue sources enabled by access to power. For example, some operators provide electricity at very low rates and make up the difference by selling appliances to new customers, thus increasing revenue not only from the sale of the appliances but also through the increased consumption of electricity by those appliances. Other operators offer appliances at a discount to increase energy sales and thus increase revenue. Others also have set up their own businesses, such as offering phone charging and other charging services to non-connected customers for a fee.

Some operators are going even further. Jumeme, a solar micro-grid developer operating in the lake region of northern Tanzania, is collecting and deep-freezing fish on site and delivering it to Dar es Salaam. Mandulis, a biomass micro-grid developer in northern Uganda, is milling maize to produce its own flour as a service to local farmers, and is selling byproducts from its processes, such as biochar for use as a fertilizer or as an alternative to charcoal. ${ }^{15}$

\section{Payment Mechanisms}

Regardless of the exact mechanism or structure for generating revenue, one common trend throughout is the increasing use of mobile money as a means to facilitate transactions. Although many remote customers might not have easy access to physical banks, many of those who connect to micro-grids do have mobile phones. Mobile money offers a fast and reliable mechanism for customers to deliver payments to power service providers - be they prepaid, post-paid, or other — and can help reduce the need for on-site staff and reduce transaction costs. However, this option is conditional on a reliable mobile money market and infrastructure being in place in the particular country or community.

\section{Existing Consumer Information}

Data on consumer demand and payments on rural micro-grids is starting to emerge. This data can be used to better understand and manage risks, develop more sustainable business models, and potentially secure financing. For example, a recent analysis conducted by SparkMeter International-a leading supplier of smart meters to micro-grids - found that the average customer makes roughly two payments per month, the average monthly consumption per customer is about $2 \mathrm{kWh}$, and the average monthly average revenue per user is around $\$ 5$ per month. ${ }^{16}$

\section{Level of Service and Technologies Deployed}

The level of service provided and the technologies that comprise the micro-grid are critical business decisions for micro-grid developers. One common way to consider level of service is Sustainable Energy for All (SEforALL) and World Bank multi-tier framework. ${ }^{17}$ It measures not only whether users receive energy services, but also whether these services are of adequate quality, reliable, affordable, safe, and available when needed. Those levels of service also map to levels of service in the QAF, which are valuable for measuring micro-grid performance against standard benchmarks. ${ }^{18}$

\footnotetext{
${ }^{15}$ See "Productive Use of Energy in African Micro-Grids: Technical and Business Considerations" (https://www.nrel.gov/docs/fy180sti/71663.pdf) for a broader discussion of approaches to and examples of integrating productive uses of energy into micro-grid business models.

${ }^{16}$ Daniel Schnitzer and SparkMeter, "What Smart Metering Data Says About Micro-Grids Trends from Sites Deployed with SparkMeter Systems” (HOMER Micro-Grid Conference, September 2017). See also, https://www.greentechmedia.com/articles/read/what-smart-meters-are-telling-us-about-microgrid-use\#gs.obu7DXQ.

${ }^{17}$ See https://www.esmap.org/node/55526 for more details.

${ }^{18} \mathrm{See}$ https://cleanenergysolutions.org/qaf.
} 
In practical terms, decisions regarding the level of service required directly influence the system design and possible technology combinations. If a developer wants to provide services that are more or less indistinguishable from grid-connected households, for example, then it might have to use a diesel generator alongside PV and battery banks to ensure 24/7 service.

\section{Target Customers}

The last major business-model decision is the target customers of the micro-grid developer. Most developers focus on communities that are a mixture of private household and small productive users (which refers to power consumption by small industry and businesses and is discussed in more detail in the Operational Bundling section below). ${ }^{19}$ Some also target long-term contracts with "anchor customers" such as telecom towers or health centers which can underwrite a large portion of a micro-grid's revenues. By mitigating the long-term revenue risk, such customers can improve the financial sustainability of the project, support upfront costs, and help attract long-term financing. A good example of an anchor tenant framework is the set of micro-grids being developed in Sierra Leone with funding from UK Aid that are centered on community health centers. ${ }^{20}$ The case study on Kalangala Renewables and Kalangala Infrastructure Services also highlights an approach to integrating reliable anchor customers into a microgrid business model (see Case Studies section below).

\section{Funders}

Although the previous section outlined various mechanisms for delivering financial support to micro-grid developers, it only briefly mentioned specific sources of investment capital. There are three primary sources of financial support—governments, donors, and private investors.

\section{Governments}

Governments often are the first line of financial backing for micro-grids due to the early stage of the industry and ambitious electrification programs. Governments can choose to support a micro-grid program through a variety of mechanisms including provision of grants, subsidies, and concessional finance and loan guarantees. However, many governments have limited public funding available for micro-grid development. Many rely on taxes or other revenues (e.g., from utilities or other state-owned enterprises) to fund electrification programs, and without support from external stakeholders such as the private sector, these governments often are unable to scale-up these programs while balancing other spending priorities.

\section{Donors}

Donor organizations can take many forms - from DFIs that provide concessional loans, to bilateral foreign aid agencies that can offer grants and direct subsidies, to non-governmental organizations (NGOs) and private charities that can have diverse goals and objectives. To date, these donors have been one of the primary financial drivers aiming to expand micro-grid markets around the world. The diversity of these donor agencies gives rise to a variety of donor-support mechanisms, though in many cases this support is channeled through governments. Some donor agencies provide concessional finance and loans or direct cash grants and subsidies directly to micro-grid developers or those parties working with them.

Nigeria currently has the largest and most diverse range of micro-grid donor programs. The two largest programs in the country are the Nigeria Energy Support Program (NESP), which has been implemented

\footnotetext{
${ }^{19}$ See pooled funds for electrical appliances in Financial Bundling section of this report. See also "Productive Use of Energy in Africa Micro-Grids: Technical and Business Considerations" (Energy 4 Impact and NREL, 2018). https://www.nrel.gov/docs/fy18osti/71663.pdf.

${ }^{20} \mathrm{See}$ http://www.ecreee.org/sites/default/files/Proposals/reoi-mini-grid_operation_in_sierra_leone_pppu.pdf for an example of an RFP showing how these micro-grids can be procured.
} 
by GIZ, and the World Bank's Nigerian Electrification Program (NEP). GIZ completed the $€ 24.5$ million Phase 1 of NESP in early 2018 and, as part of the program, helped to successfully realize six micro-grids, providing $100 \%$ grant funding for the distribution assets. GIZ recently received $€ 33$ million from the EU and the German government for funding Phase 2. The World Bank has approved a \$350 million loan through the NEP to the Nigerian government for the development of rural electrification projects in the country. About $\$ 100$ million of the funds are earmarked for the development of some 10,000 micro-grids with a total capacity of 3,000 MW, with much of this support being in the form of matching grants and results-based connection subsidies. The World Bank's grants will be implemented through the Rural Electrification Agency.

\section{Private Investors}

Private investors generally have remained on the fringe of the micro-grid market due to the lack of proven business models, low risk-adjusted returns, lack of successful exits, and micro-grid policy and regulatory risk. Investors also are wary of political and other risks at the country level. To date, most of the private investment has been made possible only through parallel support from governments or donors which can reduce project risk and increase confidence about future cash-flows.

The main types of investors in micro-grids are angel investors, venture capitalists, impact investors, and (increasingly) strategic investors. Some micro-grid developers have raised significant early-stage venture capital from impact investors. For example, PowerGen Renewable Energy raised \$4.5 million in 2017, ${ }^{21}$ Husk Power raised \$20 million in investment capital in 2018, ${ }^{22}$ and RVE SOL recently raised $€ 2.5$ million in investment capital from infrastructure partners. ${ }^{23}$

One positive trend which suggests that the micro-grid market is becoming more mature is the arrival of strategic investors. Powerhive — whose initial investors include First Solar, Caterpillar, and Total—raised $\$ 20$ million in a Series A funding round in early $2016 .{ }^{24}$ Winch Energy is $50 \%$ owned by Total Eren, which is minority owned by Total, signaling the interest of Total Eren in the micro-grid products that Winch Energy is developing. ${ }^{25}$ Other strategic investors in the micro-grid sector in Africa include Engie, EON, Schneider Electric, Facebook, and Tesla.

Some developers are exploring new strategies to raise capital from novel sources such as crowdfunding platforms and cryptocurrency. For example, Powerhive is utilizing Sun Exchange, a blockchain-based micro-funding platform, to attempt to raise $\$ 23$ million in capital to build micro-grid projects. ${ }^{26}$

\footnotetext{
${ }^{21}$ See https://www.powergen-renewable-energy.com/2017/03/29/powergen-closes-4-5m-series-a-with-dob-equityahl-ventures-and-private-investors/ for more information.

${ }^{22}$ See http://www.huskpowersystems.com/husk-power-systems-receives-20-million-investment-from-shellswedfund-engie-rassembleurs-denergies/ for more information.

${ }^{23} \mathrm{See}$ https://inventures.eu/rve-sol-raises-e2-5m-to-provide-clean-water-and-electricity-to-15k-people-in-kenya/ for more information.

${ }^{24}$ See http://www.powerhive.com/877/ for more information.

${ }^{25} \mathrm{See}$ https://www.winchenergy.com/about-us for more information.

${ }^{26} \mathrm{See}$ https://microgridknowledge.com/solar-storage-microgrids-kenya/ for more information.
} 


\section{Operational Bundling}

The previous section looked at different business models for micro-grids and some of the challenges of getting them to scale. The next two sections consider how operational and financial bundling can potentially overcome some of these challenges. There is an immediate need for novel approaches to financing micro-grids, but this depends on improvement in the operating fundamentals. The purpose of operational bundling is to realize efficiencies and economies of scale across micro-grids managed by a particular developer or across a portfolio of micro-grids owned by a given investor. The main categories of operational bundling for micro-grids in SSA are:

- Design and engineering,

- Installation and commissioning,

- Operations and maintenance,

- Customer agreements,

- Standardized productive-use offerings, and

- Performance monitoring and reporting.

These are described in the subsections below.

\section{Design and Engineering}

The theory of bundling systems together to facilitate operational and financing efficiencies often faces practical challenges in designing systems for each unique community's demand and physical footprint. A variant of this challenge exists across most power systems and there are several options to overcome it in the SSA micro-grid context.

The most fundamental decision is the mix of generation sources and energy-storage technologies for the systems. The more consistent the equipment in bundled systems, the easier it will be to procure equipment and monitor performance potentially yielding several benefits, including bringing down costs by improving developer bargaining positions with suppliers, improving operations and maintenance planning (e.g. enabling predictive maintenance across consistent equipment and configurations across micro-grids), enabling more optimal system sizing, and facilitating approaches to communications and controls can be scaled across the fleet of micro-grids. Furthermore, consistent system design can help develop a track record of performance that makes investors more confident with the level of risk.

Many developers use PV plus battery storage (typically using lead-acid batteries). Others include diesel generators that cover a small percentage of the load and provide some flexibility in system sizing (with attendant requirements for maintenance, cost, and fuel logistics). Having consistency in this dimension of micro-grid design can streamline other operational decisions (including for performance monitoring and reporting, as well as equipment purchasing). For example, if a developer decides to provide 24/7 service with diesel generation that will typically cover $10-20 \%$ of the annual load, then the developer can procure diesel generators (and fuel), PV panels, and other system components (e.g. inverters) with some consistency that could bring down costs and hone system sizing over time as performance data is collected and analyzed.

One increasingly common system-design question is the choice of battery technology. The available choices of batteries have increased following recent technological advancements and declines in costs. Lead-acid batteries are still the most widely used by developers but falling lithium-ion battery costs have led some developers to consider which battery technology best fits their business model and technical needs. There are trade-offs to consider in battery cost, availability, conditioning requirements, 
degradation-rate estimates, and useful life that factor into this decision. ${ }^{27}$ The decision to use a given technology and particular chemistry or OEM can also yield benefits in procurement and O\&M like other design choices, but it can also have important implications for enclosure design (e.g. to manage battery temperature within warranty bounds).

With the fundamental system design ready for scale, the next issue is optimizing the distribution grid design. Despite each community having a unique layout, there are tools that facilitate distribution grid design. For example, there are companies that offer web-based tools that take GPS inputs about household locations, generation type and location, and assumptions for system needs and constraints to produce distribution system designs to make the process more automated. Leveraging tools and designing internal processes to bundle elements of distribution design have the potential to decrease both the costs and the time it takes to complete micro-grid development. Again, standardized designs can also decrease real or perceived risk on system performance for prospective investors.

\section{Installation and Commissioning}

Micro-grids are expected to reliably produce electricity over decades of operation; ensuring consistent performance begins with proper system installation. There are a number of national and international standards such as International Electrotechnical Commission (IEC), Institute of Electrical and Electronics Engineers (IEEE), and national electric codes that apply to many elements of system installation, as well as a number of sources on best practices for proper wiring, vegetation management, and enclosure construction. A few examples include (1) IEEE 937, IEEE Recommended Practice for Installation and Maintenance of Lead-Acid Batteries for Photovoltaic (PV) Systems; and (2) IEC 62257-9-2 Recommendations for Renewable Energy and Hybrid Systems for Rural Electrification. Effective installation, commissioning, and documentation of as-built systems also support operations and maintenance $(\mathrm{O} \& M)$ planning and execution.

Commissioning of systems is then required to ensure that they are performing as designed. Similar to installation, there are international standards and best practices for component commissioning in microgrids, such as IEC standard 1526 for PV system testing. Standards for micro-grid testing at the system level are lacking in some technical areas and micro-grid companies will need to develop their own. System-level commissioning is particularly important, as micro-grids are complex systems that are subjected to varying environmental conditions and component degradation over many years. A robust commissioning procedure can help identify and mitigate issues that can impact the lifetime of components and thus system life-cycle cost of energy. Proper commissioning not only ensures satisfactory initial performance of systems but also provides the baseline conditions to support operations, maintenance, and troubleshooting of the system by providing a reference point for expected actual performance.

Effective and consistent installation and commissioning practices decrease variability in performance of a developer's fleet of operationally bundled micro-grids. A consistent process for installation can streamline commissioning, and doing both effectively can yield benefits across operational bundling categories. Operating from a common baseline can improve performance monitoring and evaluation, O\&M planning, and system reliability that is critical for micro-grids that serve productive-use customers.

\section{Operations and Maintenance}

Adopting consistent operations and maintenance practices can lead to savings and to decreased variation in O\&M costs, both of which lead to more bankable projects. This subsection is not intended to be an

\footnotetext{
${ }^{27}$ For more information, see "Scaling Micro-grid Deployment in Sub-Saharan Africa with Batteries." https://medium.com/power-africa/scaling-micro-grid-deployment-in-sub-saharan-africa-with-batteriesd03e24223039.
} 
exhaustive set of considerations, but discusses plans and checklists, predictive maintenance, and reserve accounts.

An O\&M plan is an essential element of successful long-term O\&M. The specific elements of an O\&M plan vary based on context but could include items such as OEM-recommended preventative maintenance measures and relevant timeframes, inventories of spare parts, repair or replacement criteria for equipment, and procedures for reacceptance testing following a repair (Walker 2016). Beyond its value to executing O\&M effectively, an O\&M plan also can be a valuable tool for ensuring that expectations for system maintenance are transparent and clear to the different actors involved in micro-grid operation. As the micro-grid industry scales, having a consistent O\&M plan for each micro-grid can improve planning across a portfolio of micro-grids and facilitate applying learning from one system to another.

A potentially overlooked component of O\&M planning that cuts across operational and financial bundling is maintaining a reserve account for ongoing O\&M needs, particularly equipment replacements. Reserve accounts are funds or financing (such as a credit line) that are set aside for future needs for equipment maintenance or replacement. There are a number of approaches for settling on the appropriate level of funding and adjusting that number on an ongoing basis but, at a basic level, the developer or system operator evaluates the likelihood of failures (and scheduled replacements) over time to ensure that the appropriate level of financing is available when it is needed. The distribution of failures over time is skewed towards later years as equipment begins to age, which increases the likelihood of needing to replace multiple pieces of expensive equipment at once (Walker 2016). Estimates can be done for individual systems, rolled up, or across a portfolio of systems calibrated to what a developer sees as an acceptable level of risk (e.g., minimum of $90 \%$ likelihood of having funds or credit on hand to cover any replacement or repair needs in a given year).

These elements of O\&M strategy are important for systems of any type, but have the potential to be particularly critical with remote off-grid micro-grids. Predictive maintenance can become particularly important given the potential delays in procuring equipment and transporting it to the site. Multiple equipment replacements can be scheduled simultaneously to minimize system downtime and planned more conservatively to avoid long unplanned outages. The O\&M plans also can account for the integration of community support in maintaining the micro-grid, where appropriate.

\section{Customer Agreements}

Moving from technical components of system design and management to relationships with the communities that micro-grids serve, this subsection covers the value of strong customer agreements to successful operational bundling. Developers often create tailored customer agreements for each microgrid in the pilot and demonstration phase of their growth, but consistent customer agreements are an important step in scaling business operations. For example, customer agreements can set terms or expectations for planned and unplanned downtime, which influences a developer's ability to plan O\&M and equipment replacement effectively across a fleet of micro-grids.

From the perspective of operational bundling, laying out each of these topics in a customer agreement is important for establishing consistent operations across multiple communities and avoiding communityspecific challenges that can arise from the lack of clear expectations. For example, some developers have reported poorly set customer expectations constraining micro-grid operations for years, which can require developing unique plans for certain micro-grids and result in increased costs. Effective customer agreements can also be used as a tool for marketing to new communities and for decreasing the time from initial community engagement to signing up customers by opening discussions with concrete terms for the level of service the micro-grid would provide.

Customer agreements typically are developed to satisfy legal requirements, but their purpose can be broadened to establishing clear expectations between developers and communities (Lockhart et al. 2018). 
A clear customer agreement can also be an important aspect of educating investors and other stakeholders about a developer's business model. The items that a customer agreement can include vary based on context, but ideally include the following topics:

- Information on plans and pricing,

- Which devices can be connected to the micro-grid,

- Roles and responsibilities for developers, communities, and other stakeholders,

- Expectations for system reliability and availability (e.g., the amount of expected downtime in a given year), and

- Safety protocols for the developer and community to follow.

Larger anchor tenants and their investors may require going beyond customer agreements that are typical for communities that are a mixture of private households and small productive users. Agreements for those anchor customers can build on best practices in standard power purchase agreement (PPA) contracts from other settings (e.g., U.S. residential and commercial solar markets). The benefits of standard PPAs are similar to the overarching advantages of bundling, including transparency (which can improve ease of due diligence for investors), decreased transaction costs, faster contract execution, and scalability. Components of standard contracts vary, but can consist of expanded terms and conditions, performance expectations or guarantees, and options for contract termination or transfer. ${ }^{28}$

\section{Standardized Productive Use Offerings}

Encouraging the productive use of energy (PUE), which refers to power consumption by small industry and businesses, can be an important tool for encouraging more consistent demand. Productive users of energy typically demand more power than a residential customer does, and can have more specific requirements, but their demand can contribute to revenue growth and stability. The opportunities for supporting productive uses in African micro-grids are discussed in detail in "Productive Use of Energy in African Micro-Grids: Technical and Business Considerations" (Booth et al. 2018). A few examples of PUE include:

- Ice-making;

- Milling (e.g., maize, cassava, sorghum);

- Carpentry and other woodworking;

- Egg incubation; and

- Water treatment.

The role of a micro-grid developer in encouraging productive use can take a variety of forms. At its most basic, developers can take productive use into consideration when designing systems. This can include considerations such as use of single-phase versus three-phase power, adjusting and planning for lower power factor, or assessment of inductive load impacts. More-active roles in supporting productive use can include designating productive use zones close to generation sources, selling or leasing productive use appliances or equipment, and more flexible payment or financing options. Lastly, developers can choose to run productive use businesses themselves as a standard component of micro-grids that they build and operate (Booth et al. 2018). Those options need to be adapted to a given developer's business model, level and type of capital available, and human capacity. Experimentation with productive use at the pilot and

${ }^{28}$ See https://widgets.nrel.gov/financere/interactive-solar-ppa/ for sample components of a standard PPA. 
demonstration stage can yield valuable data to steer decisions on what productive approach to scale more broadly.

When productive use is scaled across a portfolio of micro-grids, products or service offerings can be honed and risks mitigated and diversified across business types. Robust data on productive users of energy across a number of micro-grids can help investors better estimate profitability over time and the economic dynamics of the communities that micro-grids serve. On the part of the community, pairing micro-grids with thoughtful approaches to productive uses of energy can clarify pathways to economic development that the micro-grid can facilitate.

\section{Performance Monitoring and Reporting}

As mentioned previously, the QAF defines a range of service levels that ensure safe, quality, and affordable delivery of electricity, and provides an accountability framework that can be used to determine whether an agreed-upon service level is delivered. One of the key components to operational bundling of multiple micro-grids is consistency and availability of data collection and reporting. A common system for classifying customers and levels of service provided - supported by the QAF's standard monitoring and performance-reporting protocols - can make it easier to streamline due diligence, bundle micro-grids together, and access larger-scale financing. Data collected from implementation of the QAF (e.g., payment-collection rates, customer characteristics, electrification rates) can increase investor confidence and reduce the risk profile of micro-grids. It also can improve operational performance by collecting operation and customer data across a larger sample of projects and enabling more effective learning.

It is important to identify an appropriate level of both quantitative and qualitative data to be collected and to find a balance between ensuring reliability and quality of service and the level of burden placed on the micro-grid developer or operator. There is also a limit to how much data can be analyzed and meaningfully contribute to decision making. Quantitative data can be collected largely through automated recording instruments, such as smart meters and power-system monitoring equipment, which helps reduce the burden of collection.

Key metrics of potential interest to financiers are detailed in Quality Assurance Framework for MiniGrids (Baring-Gould et al. 2016). Each project and investor have different data needs, however, so some of the data listed might not be needed and some additional data might need to be collected.

\section{Other Business Functions}

There are many other business functions that are standardized during the scale-up of operations. As micro-grid companies grow they will need to standardize functions such as staffing, marketing, branding, and public relations. These types of components are critical to overall success, but are less directly linked with system development and performance. There also are other issues that will arise as companies and the industry mature, such as plans for reuse or recycling of equipment (e.g., batteries) that have reached the end of their useful life.

\section{Operational Bundling Supporting Bankability}

The common link between these operational activities is the need for micro-grid components to last and perform as designed and for expected systems' revenues to be well understood. These activities help ensure that the revenue estimated for the system will be received, risks are reduced, and investors are able to achieve their expected rates of return. As part of investment due diligence, some investors might ask to review developer procedures for items such as installation or commissioning or to review their customer agreements. Having well-documented and standardized processes and procedures for these items will support this due diligence, provide investors with confidence, and make financing easier to obtain. 


\section{Financial Bundling}

The previous section looked at how operational bundling can improve the business fundamentals of micro-grids. This section examines financial bundling of micro-grids in detail, namely the aggregation of projects into portfolios to attract more private investors through the larger ticket size and portfolio derisking. It starts by examining the barriers to financing and the risks in different parts of the micro-grid value chain, then looks at three innovative approaches to financial bundling.

\section{Barriers and Risks}

The barriers to financing are similar to the barriers around business models because the propensity of an investor or lender to provide financing is tied to the strength of a developer's business model. The high cost of power supply in remote areas and uncertainty around customer demand and willingness and ability to pay can affect the ability of a project to recover its costs and make returns on the initial investment. In addition to these business-model issues, micro-grids face other challenges raising financing because of their small transaction size and the low level of understanding and awareness of micro-grid risks by the broader financing community.

The rest of this section looks at how the risks of a micro-grid investment vary according to the phase in the life cycle of a project. Broadly speaking, there are three main phases: development, construction and commissioning, and operations. The further the project advances through these steps, the lower the risk and the greater the range of financing options available.

During the development phase, the developer must select a site and secure land rights, assess local demand for power (including potential PUE), develop a technical design for the generation and distribution systems, develop a business model, and obtain the required licenses and approvals. Failure to satisfactorily address all these items can put the future of the project at risk. This is the riskiest stage in the project, but also is the stage requiring the lowest levels of funding. Developers whose micro-grids are all at the development stage generally will find it harder to raise capital than the developers with operating projects. The two most likely sources of capital during this development phase are grants or subsidies and equity, mainly from social impact investors or angel investors.

During the construction and commissioning phase, the developer is subject to the performance of its contractors or staff and external events which could result in project delays, cost overruns, and quality issues. For most solar micro-grids, the construction risks are relatively manageable, although the capital expenditure required is much greater than in the development phase. The two most likely sources of capital during this phase are grants and equity, although debt financing might also be possible for developers that already have some operating projects.

During the operational phase, the main risks include lower-than-expected demand for electricity, customer defaults, changes in regulations, regulatory risk, technical and connectivity issues, political unrest, foreign exchange risk, ${ }^{29}$ O\&M-related risks (e.g., equipment failure, higher-than-expected costs), and natural disasters - such as droughts - which can significantly damage the local economy. One of the challenges with most micro-grids is that, unlike larger projects, they tend not to have long-term offtake agreements which bring increased revenue certainty and improve the capacity to support long-term debt. The main risk with larger projects is late payment by the offtaker rather than non-payment. Micro-grids tend to rely more on shorter-term (e.g., weekly or monthly) prepayment models by their local community customers, so the risk of late payment is mitigated. They have little visibility on long-term demand,

\footnotetext{
${ }^{29}$ For more information on foreign exchange risk, see "Green Mini-Grids in Sub-Saharan Africa: Analysis of Barriers to Growth and the Potential Role of the African Development Bank in Supporting the Sector" (Energy 4 Impact and Inensus, 2016), pp. 24, 25, 30.
} 
however, especially in rural areas that have never been electrified previously. The key question for any financier is whether the micro-grid is able to generate sufficient revenue to cover costs. There is potentially scope for debt financing in this phase, subject to the challenges outlined elsewhere in this report.

\section{Financial Bundling Strategies}

This section examines different models for financial bundling of micro-grids such as pooled funds, crowdfunding, and export finance, and considers the benefits and drawbacks of each model.

Financial bundling aggregates funds from different investors for the purposes of various types of microgrid investment. Investors in bundled micro-grid investments can potentially benefit from economies of scale, resulting in lower transaction costs, risk diversification, and more professional management. The aggregated funds can have different objectives and target different investor groups. The bundling approaches described below are oriented towards funding operations and capital investments or supporting electrical appliances purchases for households or businesses to support for productive use of electricity. Some target institutional investors and high-net-worth individuals; others - such as crowdfunding platforms - are targeted more towards retail investors. They can be equity funds, debt funds, grant programs, or a mixture of all three, and can be managed by professional investment management firms ${ }^{30}$ or by the micro-grid developers themselves.

\section{Pooled Funds for Micro-Grid Operations and Growth}

A micro-grid growth fund is a mechanism for multiple investors to invest in the development, construction, and operation of multiple micro-grid developers or projects. This approach is potentially easier, more cost effective, and less risky for investors than if they were to be the only investor directly funding individual micro-grids. The potential advantages ${ }^{31}$ of such a fund can include the following.

- The fund can reduce transaction costs through standardized processes (e.g., project identification, evaluation and due diligence, legal setup costs) and, in so doing, improve individual project viability across multiple projects.

- Economies of scale potentially can be created by spreading project development costs and operating expenditure across multiple projects. Development costs for individual projects (e.g., for feasibility studies, demand assessments, technical designs, financial modelling, and potentially licensing and permitting) can be reduced if sites are clustered close together. The costs of operations, maintenance, revenue collection, transportation, data collection and evaluation, and general corporate services can be shared between projects and costs can be reduced through bulk purchasing of goods and services.

- The ability to reach a wider group of investors might be improved by increasing the size of the investment. An individual $100-\mathrm{kW}$ solar battery micro-grid is likely to cost approximately $\$ 350,000$, which is too small an investment for most investors and banks, although it is still viable for crowdfunding platforms. ${ }^{32}$

\footnotetext{
${ }^{30}$ Energy-access fund managers include Acumen, Bamboo Capital Partners, Camco, Crossboundary Energy, Energy Access Ventures, InfraCo Africa, Lion's Head, Microgrid Investment Accelerator, responsAbility Investments, SunFunder, and Schneider Electric Energy Access Fund.

${ }^{31}$ See "Increasing Private Capital Investment into Energy Access: The Case for Mini-Grid Pooling Facilities" (UNEP, 2015), Ch. 9.

${ }^{32}$ For more information on micro-grid cost benchmarks, see "Operational and Financial Performance of Mini-Grid DESCOs: Findings and Insights from Pioneer Benchmarking of this Emerging Sector” (IFC, Jan. 2017 ), p. 15.
} 
- The ability to access new types of financial products ${ }^{33}$ through bigger investment opportunity sizes is potentially increased.

- Investor risk is potentially reduced through diversification across multiple projects.

- Project performance monitoring and evaluation can be improved by collecting data on multiple projects (as discussed in the operational bundling section of this report).

- The scope for refinancing individual projects using lower-cost capital as the projects become operational is potentially increased.

Most micro-grid start-ups rely on grant and equity funding for the development and construction of their first micro-grids. This is because the process of identifying sites, assessing demand, and getting the relevant licenses and approvals is long and uncertain, and most lenders are reluctant to lend to companies that do not have a track record or offer loans to projects without long-term visibility about future revenue generation. Once a fund or a developer has built one or two micro-grids and demonstrated over time that that the micro-grids are generating stable revenues, however, it might be better-positioned to get a loan from a bank or a peer-to-peer business lending platform. By taking out a loan, the developer can release equity from the operational projects to use to develop more micro-grids. As the developer brings more micro-grids into operation, it potentially can refinance its initial loans with larger loans that have more favorable terms.

Despite the advantages described above, there are very few examples of dedicated micro-grid funds in SSA - the authors know of at least one professional fund manager that is raising funds for a micro-grid pilot fund, but the amounts involved are small (less than $\$ 10$ million) and the business case remains unproven. Existing energy-access funds are able to invest in micro-grids, but the proportion of funds going to micro-grids remains small. For example, Sunfunder, a donor-backed lender to solar companies, has approved very few loans for micro-grids.

Most fund managers are still wary of investing in micro-grids, whether on their own or as part of a portfolio. Even if they do invest, the level of complexity and administrative burden of managing a portfolio of micro-grid projects is still likely to be significant and there is a need for a fund to provide proof of concept. Given the level of micro-grid deployment to date, there is also potential to create unintended correlated risks through selecting micro-grids in the same geographic area when options are limited.

\section{Pooled Funds for Electrical Appliances}

Another bundling approach is to set up a revolving fund to help micro-grid operators provide concessional loans to micro-grid users for electrical equipment. ${ }^{34}$ The intent of such a fund would be to stimulate local demand for electricity - especially from productive users ${ }^{35}$ — and improve the viability of the micro-grids. Without financial support for these potential users, micro-grids often struggle to increase

\footnotetext{
${ }^{33}$ Examples of financial products that might be more accessible with a bigger investment opportunity sizes include asset finance, project finance, export credit finance, and carbon credits. There also could be potential for off-balance sheet accounting treatment and risk-tiering of capital.

34 The fund is likely to have a greater impact if it is used for electric appliances for productive users. It also potentially could be used, however, to cover the cost of household connections and indoor electric installations (e.g., meters, wiring, sockets, light bulbs). One of the advantages of funding installations is that developers can ensure that installations are carried out by certified engineers in line with proper health and safety standards. ${ }^{35}$ See also "Productive Use of Energy in Africa Micro-Grids: Technical and Business Considerations" (Energy 4 Impact and NREL, 2018). https://www.nrel.gov/docs/fy18osti/71663.pdf.
} 
local commercial uptake of electricity and reach the critical level of sales necessary for a sustainable business.

Productive users are also important to enhance the economic and social-development impact of microgrids and rural electrification programs more broadly. Appliance financing is an important component of enterprise development and productive use of electricity supplied by micro-grids. It often is needed to cover the capital costs of productive-use appliances which are relatively high ${ }^{36}$ compared to the financials of a typical village micro-entrepreneur.

The seed capital for such a pooled fund would likely come from donors or philanthropic organizations and then the repayments from the loans could be used to finance more equipment. Once the model is proven, the potential for private capital or developer-led funds could grow. Many donors are discussing the idea of a standalone productive-use fund, but so far nothing significant has been launched. Support for productive use, however, often is included in micro-grid tenders and other donor initiatives.

The main advantages of a pooled fund for appliances include the following:

- The fund takes the burden of appliance financing off the developer's balance sheet, so the developer can focus its time on running the micro-grid efficiently.

- Developers keep direct control over the financing strategy and the choice of appliances, which must be appropriate for both the entrepreneurs and the micro-grid.

- The fund is potentially an easier option for developers than providing appliance financing through local financial institutions or suppliers of equipment. It often is not easy to find suitable financial institutions and equipment suppliers in remote rural areas, especially ones that are willing and able to lend to micro-entrepreneurs on acceptable terms (i.e., reasonable collateral requirements and interest rates). This is particularly the case for start-ups or new business activities that have no track record. ${ }^{37}$

- The fund can provide grants for technical assistance, for both the developers and local entrepreneurs. Support for developers could include analysis of local value chains, demand-side management strategy, and customer service. Many also lack the skills and resources for credit assessment, loan monitoring, and following up on loan repayments. Support for local entrepreneurs could include advice on commercial, financial, and business model topics and technical and engineering advice including use of the electrical equipment.

- By providing support to multiple developers and projects, the fund is less exposed to the performance risk of a single developer and the payment risk of customers from an individual grid. It also is more likely that the funds can be utilized in an efficient manner if there is an option to spread them across multiple projects.

Micro-grid developers often use a lease-to-own model of appliance financing based on consumer finance or microfinance principles. Most appliance financing is for 12 months or less and requires the customer to pay an up-front deposit of up to $30 \%$ of the cost of the appliance. The cost of electrical appliances varies, but typically is within the size range of most microfinance institutions (typically from $\$ 100$ up to $\$ 10,000)$. The customer usually makes monthly appliance repayments in addition to the customer's monthly electricity payments. Therefore, the business case for productive-use equipment activities must account for both the cost of electricity and the monthly repayments. Ownership of the appliance transfers

\footnotetext{
${ }^{36}$ The cost of a lathe and an electric mill are likely to be about $\$ 1,000$ and $\$ 2,000$, respectively.

${ }^{37}$ Many micro finance institutions require businesses to have at least 6 to 12 months of cashflow before they will consider providing a business with a loan.
} 
to the customer once the loan or lease is fully repaid. In case of default, the appliance can be repossessed or electricity can be disconnected to incentivize the entrepreneur to make the necessary repayments.

\section{Crowdfunding}

Crowdfunding platforms can serve a similar set of investment objectives as the pooled funds for operations and growth or pooled funds for electrical appliances described above. What distinguishes crowdfunding from those other two bundling approaches is that it targets retail investors rather than highnet worth investors. This opens up micro-grid investments to a larger set of potential investors while still accessing the benefits of pooled funds, such as reducing transaction costs or realizing economies of scale. Crowdfunding is receiving a great deal of attention as a source of debt or equity for energy-access companies. With the exception of Bettervest, however, which has run successful campaigns to construct a few micro-grids in Nigeria, and one micro-grid campaign run by Trine in Kenya, none of the other major peer-to-peer lending platforms in the space (e.g., Lendahand, Energise Africa) have yet run campaigns for micro-grids.

It is interesting that there have been many more peer-to-peer loans going to solar home-system companies than to micro-grid developers. This is partly a question of the perceived risk, but it also is a question of the product offering and size of investment needed. Most crowd lenders prefer shorter-term loans (e.g., 3 years or less) with regular repayments (e.g., every 6 months). Their product is ideally suited for pay-as-you-go ${ }^{38}$ (PAYG) solar home-system companies, which provide credit to end-users, enabling them to pay in instalments, for instance over a 2- to 3-year period, before they take full ownership of the system. Micro-grids, in contrast, require longer-term loans and owners might not be able to make regular repayments in the early years.

Some developers have experimented using crowdfunding for financing end-users, even helping them to purchase the micro-grid. One developer (PowerGen Renewable Energy) was a field partner of Kiva, a not-for-profit crowdfunding platform that connects people through lending to alleviate poverty. Although PowerGen is no longer an active field partner, it directly provided $\$ 67,000$ in concessional loans to 71 customers in Kenya using funds from Kiva lenders. ${ }^{39}$ According to Kiva, the funds are used to "provide in-kind micro-grid loans to groups of borrowers with affordable interest rates and manageable loan terms. Current loan terms vary between 2 and 7.5 years, with a flexible repayment schedule and interest rates between $5 \%$ and $10 \%$. Once the loan is fully repaid, the grid will become the property of the community, and rates will be reduced to cover only the metering cost and ongoing maintenance." 40

\section{Export Credit Finance}

Another option for financing that hinges on effective bundling is export credit finance. Export credit agencies (ECAs) promote equipment-based exports on behalf of national governments by facilitating competitive long-term funding. They also provide guarantees and political risk insurance to exporters and their partner banks against risk of non-payment by foreign buyers. Most ECAs do not lend directly, so exporters have to work through international and local banks. Export credit finance is best suited for larger transactions (typically of more than $\$ 20$ million) because of the relatively high fixed setup costs, so is unlikely to work for micro-grids unless they are bundled.

\footnotetext{
38 The term "PAYG" covers a range of technologies, payment rules, and ownership and financing structures, which allow the end user to pay for an electricity product or service in affordable installments instead of a lump-sum payment, and incorporate a technology that disables the system if payment is overdue.

${ }^{39}$ Numbers correct as of October 5, 2018. For more information on the loan terms and current loans outstanding, see https://www.kiva.org/about/where-kiva-works/partners/340.

${ }^{40}$ See https://www.kiva.org/about/where-kiva-works/partners/340 for additional details.
} 


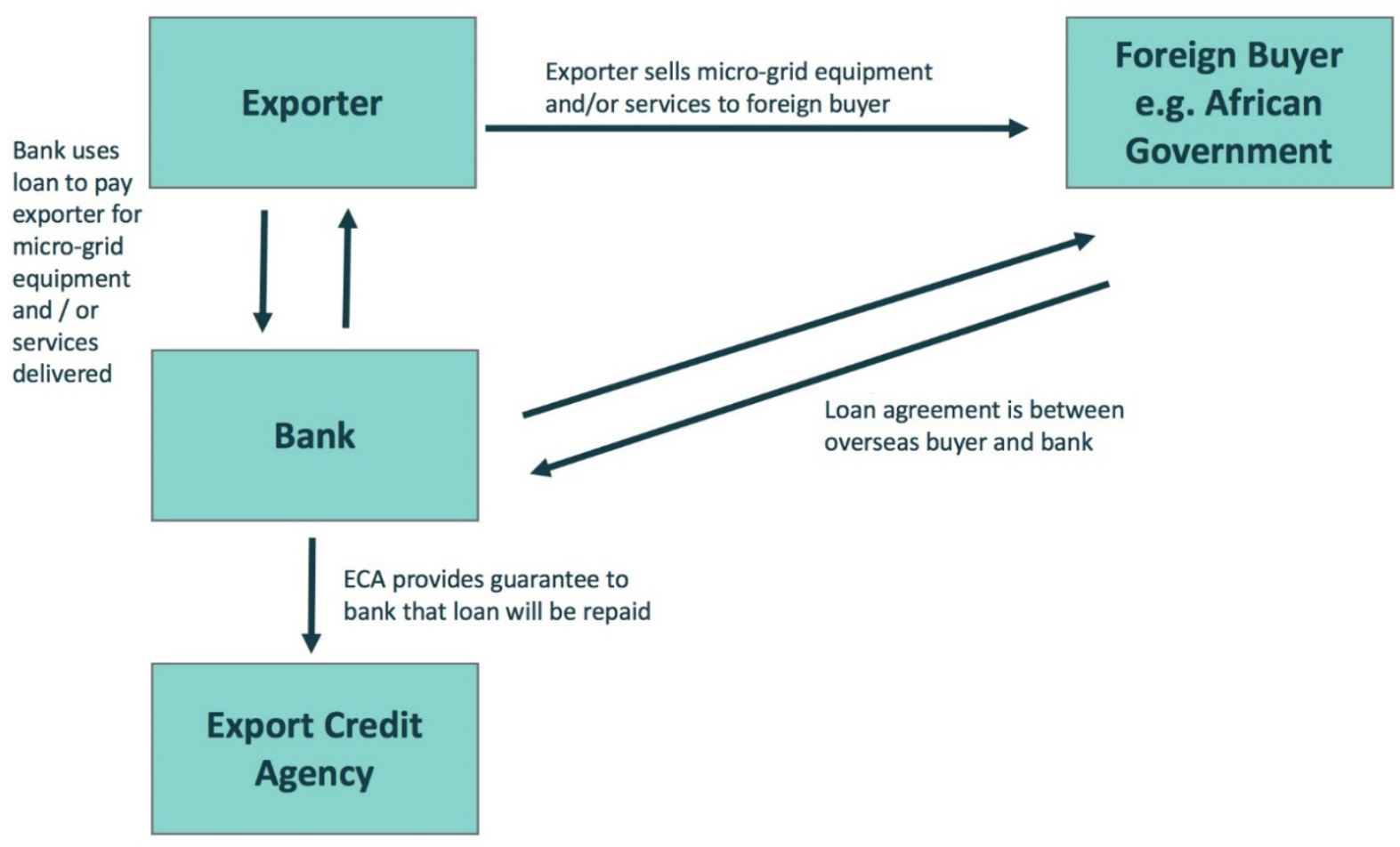

Figure 3. Selling micro-grid equipment to African governments using export finance.

Some developers are considering using export credit finance to sell their micro-grid technologies to African governments ${ }^{41}$ and manage the units on behalf of the government (see Figure 3 ). The main benefits of this approach are as follows.

- The exporter (the seller of the micro-grid technology) is able to secure larger orders, potentially for hundreds of micro-grids.

- The exporter is paid as though it has a cash contract.

- The buyer or borrower (the African government in this instance) has time to pay over a number of years and can borrow at a very competitive fixed rate of interest.

- Risks can be allocated to the parties that are most able to handle those risks. For example, the risks around licensing and changes in law could be allocated to the government, although responsibility for the installation and technical operation of the micro-grids is left to the private sector.

- The banks are largely shielded from political risk and the risks of micro-grid development and operation.

For exports coming from Organisation for Economic Co-operation and Development (OECD) countries, the maximum amount of the loan typically is $85 \%$ of the export contract value. A minimum of $15 \%$ of the contract value must be paid directly to the exporter by the buyer before the loan can be disbursed. Most ECAs can also consider support for foreign content (that is, the cost to the exporter of purchasing goods or services from subcontractors outside the main exporting country).

\footnotetext{
${ }^{41}$ Winch Energy has created the Remote Power Unit which is a containerized PV battery solution that can provide 24/7 power via micro-grids. The company's business model is to either sell power as an independent power producer or, using UK Export Finance, sell technology to African governments. https://www.gtreview.com/supplements/gtr-uk-2018/roundtable-young-exporters-say/.
} 


\section{Case Studies}

This section describes two interesting developer case studies that illustrate different aspects of operational and financial bundling described above.

1. Kalangala Renewables and Kalangala Infrastructure Services. A case study of a 1.6-MW micro-grid in Uganda funded by debt and equity from DFIs as part of a much larger transportand water-infrastructure project.

2. Ruaha Energy. A case study of a private developer which has used grants and U.S. private placements to fund village micro-grids and grid-tied renewable projects in Tanzania.

\section{Case Study 1. Kalangala Renewables and Kalangala Infrastructure Services (Uganda)}

\section{Company Overview}

Kalangala Renewables (KR) is a 1.6-MW renewable power system located on Bugala Island on Lake Victoria in Uganda's Kalangala District. It comprises a solar-diesel generation unit (600-kWp PV and 1.0-MW diesel generators), a 33-kV transmission system, a low-voltage distribution system, and a prepaid metering system.

Kalangala Renewables was commissioned in December 2014 and started supplying customers in March 2015. It currently supplies power to 3,100 households and 24 commercial customers-including a few hotels and small enterprises - and has a distribution network which stretches to $67 \mathrm{~km}$ in its longest section. The main industries on the island are fishing (along the shores of Lake Victoria), agriculture (oil palm growing, timber), and tourism. 


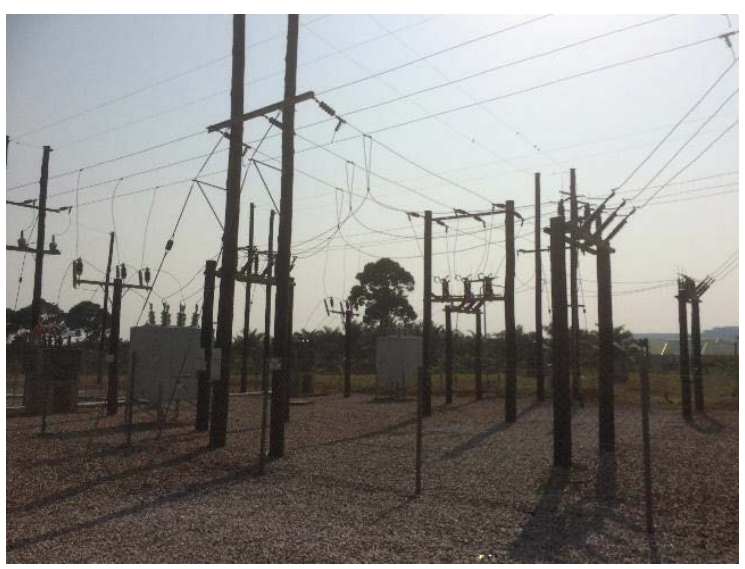

Figure 4. Kalangala Renewables' substation. Photo by Energy 4 Impact.

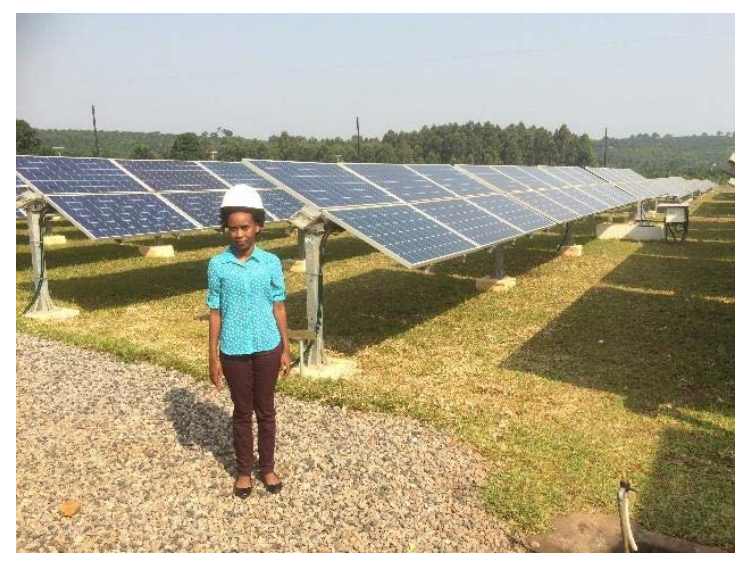

Figure 5. Kalangala Renewables' solar PV array. Photo by Energy 4 Impact.

\section{Financial Bundling}

Kalangala Renewables was developed and financed as an integral part of Kalangala Infrastructure Services (KIS), a \$49 million mixed-utility project company which also includes transport (two on-off passenger and vehicle ferries, and an upgraded trunk road) and water supply (solar-powered water supply systems to Kalangala and other settlements). Kalangala Renewables accounted for about \$16 million of the original KIS investment.

The multi-utility model played a key part in the successful financing of KIS and KR. The project's backers took comfort from the revenues generated by the long-term government contracts for the ferries and the road and therefore were able to accommodate the revenue and demand uncertainty around the power business. This business model structure is an example of the "anchor customer" approach described above in the Mechanisms of Financial Backing section.

Kalangala Infrastructure Services bundled a number of funding mechanism together to finance the project, including a mixture of equity from DFIs, and DFI and commercial debt backed by guarantees. It also received an output-based grant to subsidize connections. KIS is owned by InfraCo Africa (54\%) and Ugandan Development Corporation (46\%). InfraCo Africa is a donor-backed company which invests in early-stage energy and infrastructure projects in Africa. Debt financing was provided by Emerging Africa Infrastructure Fund (a DFI) and Nedbank Capital (a commercial bank). Joint debt guarantees were provided by GuarantCo and USAID. 


\section{Case Study 2. Ruaha Energy}

\section{Company Overview}

Ruaha Energy is a Tanzanian private developer and operator of rural and small urban electrification projects, including village micro-grids (solar PV with biomass gasifiers), grid-tied solar PV, and small hydro plants. The company — which was founded in Dar es Salaam in 2013 - is an independent power producer, distribution network operator, and civil construction company. It also has a partnership with an Indian company to assemble and market prepay electricity meters in Tanzania.

Ruaha is developing village micro-grids in the Kilosa District of Tanzania, which is about $300 \mathrm{~km}$ west of Dar es Salaam. So far, the company has installed one 50-kWp micro-grid serving the village of Zombo and two nearby villages. The micro-grid has been operating since December 2016, and has 150 connections, with another 50 likely to be connected soon. Ruaha is planning to eventually double the generation capacity of Zombo from 50-kWp to $100-\mathrm{kWp}$. Presently, Ruaha is developing micro-grids in three other village clusters, including a $450-\mathrm{kWp}$ plant which eventually will be connected to two gridtied mini-hydro plants that the company also is developing. Funding for the village micro-grids (expansion of Zombo plus the three village clusters) will mainly come from new grants.

Ruaha is developing several grid-connected projects, including two 1-MW solar PV plants and two small hydro plants (500 kW and $200 \mathrm{~kW}$ ). In January 2018, it signed a standard power purchase agreement with Tanesco, the state electric utility, for the first solar PV project in Kilosa Town, and plans to start delivering power to the grid by the end of 2018. These projects are likely to be financed by a mixture of new grants, equity, bank debt, and asset finance. Ruaha has built a regional operations and maintenance facility at the Kilosa Town site for both the grid and off-grid projects being developed in Kilosa.

\section{Financial Bundling}

Ruaha Energy has been very creative in its funding strategy, raising corporate equity for the village micro-grids and on-grid projects, and securing grants for individual projects. In November 2016, it successfully raised funds from a U.S. equity private placement ${ }^{42}$ and now is planning to raise more funds through debt and equity private placements or possibly equity crowdfunding. So far, the company has been awarded five project grants for technical assistance ${ }^{43}$ and capital expenditures, ${ }^{44}$ and it is hopeful that it will secure additional grants soon. Though the various types of investors and investment vehicles that Ruaha accessed are not coordinated in pooled funds or crowdfunding mechanisms, taken together they point to the potential to bundle different investors with varying levels of risk tolerance to fund microgrid development in a way that none of the investors could individually.

\footnotetext{
42 U.S. Securities and Exchange Commission Regulation D, Rule 506.

${ }^{43}$ These include: A $\$ 455 \mathrm{~K}$ technical-support facility from REPP to fund part of the costs of feasibility studies for four 1-MW grid-connected solar PV projects, as well as part of the costs of legal and lender due diligence; a $\$ 600 \mathrm{~K}$ grant from the U.S. Trade Development Agency to fund a pre-feasibility study for three small hydro projects of $10 \mathrm{MW}$ each on the Upper Lukosi River; and a \$95K TEDAP grant to partly fund the preliminary feasibility studies for the biomass/solar PV grid and off-grid projects, and an early-stage assessment of two 5 MW run-of-river hydro projects on the Lower Lukosi River.

${ }^{44} \mathrm{~A} € 630 \mathrm{~K}$ EEP grant to partly cover the capital expenditures of constructing the generation system and distribution network for the Zombo micro-grid; and a €245K EEP grant for the 1-MW grid-connected solar PV project in Kilosa Town to partly cover the capital expenditures costs of the project. (The EEP is the Energy and Environmental Partnership, a program funded by the governments of Finland, Austria, and the United Kingdom.)
} 


\section{Conclusions}

There is no "one-size-fits-all" business or financing model for micro-grids. Each particular micro-grid project or bundle of projects has its unique characteristics and requirements based on the local context and environment. For the long-term sustainability of any micro-grid project, however, it is important to consider how it is conceived and selected, how development and operational costs are recouped, and who is responsible for ownership and operation of the system.

Governments, developers, and donors all can play a role — as leaders or partners - for identifying and initiating projects. Different revenue models - post-paid and prepaid cost-recovery and alternative revenue models such as selling or renting appliances and other business services - are being applied and tested. Ownership and responsibility for operation is usually with governments or developers, but in some cases a blended approach — where both governments and developers have some responsibility — might be the more effective solution. All of these approaches have been shown to work under different circumstances.

Almost all micro-grid business models today still require some form of incentive or financial support to get off the ground. This can come in the form of subsidies (such as cash grants or production-based subsidies), concessional loan rates, loan guarantees, or simply private investment such as that coming from angel investors. The funding to support any of these incentive programs can come from governments or - more commonly today-donors. The ultimate goal is that such incentives make microgrids attractive enough for private investors to fund the balance of the project.

All of these business models potentially can be brought to scale through operational and financial bundling, which can create economies of scale, reduced transaction costs, and diversification of risks. Operational bundling approaches can include performance-monitoring and reporting approaches inspired by the QAF, O\&M improvements such as consistent planning across micro-grids and reserve accounts, effective customer agreements, or partially automated distribution system design. Financial bundling in turn can increase access to capital through pooled funds, appliance financing schemes, and crowdfunding. Taken together, they have the potential to accelerate private investment and facilitate access to lower-cost capital for micro-grid developers and owners. 


\section{List of References}

African Development Bank Group (2016). "Green Mini-Grids in Sub-Saharan Africa: Analysis of Barriers to Growth and the Potential Role of the African Development Bank in Supporting the Sector." Energy 4 Impact and Inensus. https://www.energy4impact.org/file/1818/download?token=j67HKZEy.

Baring-Gould, Ian, Kari Burman, Mohit Singh, Sean Esterly, Rose Mutiso, and Caroline McGregor (2016). "Quality Assurance Framework for Mini-Grids.” NREL/TP-5000-67374. Golden, CO: National Renewable Energy Laboratory. http://www.nrel.gov/docs/fy17osti/67374.pdf.

Booth, Samuel, Xiangkun Li, Ian Baring-Gould, Diana Kollanyi, Abishek Bharadwaj, and Peter Weston (2018). "Productive Use of Energy in African Micro-Grids: Technical and Business Considerations." NREL/TP-7A40-71663. Golden, CO: National Renewable Energy Laboratory. https://www.nrel.gov/docs/fy18osti/71663.pdf.

EnDev (Energising Development) (2017). "Driving Markets to Scale: Lessons Learned from Stimulating Energy Access Markets with Results Based Financing." https://endev.info/images/3/34/EnDev_RBF_lessons_learnt_report_2017.pdf.

Energy 4 Impact (2018). "Crowd Power: Success and Failure: The Key to a Winning Campaign.” https://www.energy4impact.org/file/1996/download?token=xiKti84u.

Energy 4 Impact (2016). "Crowd Power: Mapping the Market for Energy Access." https://www.energy4impact.org/file/1697/download?token=CLBAAi7Q.

International Finance Corporation (IFC) (January 2017). "Operational and Financial Performance of Mini-Grid DESCOs: Findings and Insights from Pioneer Benchmarking of this Emerging Sector." https://sun-connect news.org/fileadmin/DATEIEN/Dateien/New/IFC_Minigrids Benchmarking_Report_Single Pages January 2017.pdf.

Kiva and Powergen Renewable Energy As Field Partners. https://www.kiva.org/about/where-kivaworks/partners/340.

Lockhart, Eric, Samuel Booth, and Ian Baring-Gould (2018). "Customer Agreement Considerations for Micro-Grids in Sub-Saharan Africa.” NREL/TP-7A40-70777. Golden, CO: National Renewable Energy Laboratory. https://www.nrel.gov/docs/fy18osti/70777.pdf.

Reber, T.J., S.S. Booth, D.S. Cutler, X. Li, J.A. Salasovich (Feb. 2018). "Tariff Considerations for MicroGrids in Sub-Saharan Africa.” NREL/TP-7A40-69044. Golden, CO: National Renewable Energy Laboratory. https://www.nrel.gov/docs/fy180sti/69044.pdf.

UNEP (United Nations Environment Programme) (2015). "Increasing Private Capital Investment into Energy Access: The Case for Mini-Grid Pooling Facilities."

https://gpc.stanford.edu/sites/default/files/unep.pdf.

UK Aid (2017). “Auctions as a Potential Mechanism to Accelerate Green Mini-Grids in Africa." Prepared by Oliver Wyman. https://assets.publishing.service.gov.uk/media/59d73990ed915d4937c45b7e/MiniGrids_Auction_Study_FINAL_FULL.pdf.

Walker, Andy (2016). "Best Practices in Photovoltaic System Operations and Maintenance: 2nd Edition." NREL/TP-7A40-67553. Golden, CO: National Renewable Energy Laboratory. https:/www.nrel.gov/docs/fy17osti/67553.pdf 


\section{www.nrel.gov/usaid-partnership}

\section{USAID}

United States Agency for International Development 1300 Pennsylvania Avenue NW • Washington, DC 20523 $+1-202-712-0000$

www.usaid.gov

\section{Katrina Piell}

Senior Energy Advisor and Lead, Beyond the Grid USAID | Power Africa

Pretoria, South Africa

Office: +27 12-452-2086 | Mobile: +27 72-710-5162

www.usaid.gov/powerafrica | kpielli@usaid.gov

\section{ONREL}

National Renewable Energy Laboratory

15013 Denver West Parkway • Golden, CO 80401

$+1-303-275-3000$

www.nrel.gov

\section{Samuel Booth}

Senior Project Leader, Micro-Grids

National Renewable Energy Laboratory (NREL)

Office: +1-303-275-4625 | Mobile: +1-303-513-6786

www.nrel.gov | Samuel.Booth@nrel.gov

NREL is a national laboratory of the U.S. Department of Energy, Office of Energy Efficiency \& Renewable Energy, operated by the Alliance for Sustainable Energy, LLC. 